\title{
Comparing Cash and Voucher Transfers in a Humanitarian Context: Evidence from the Democratic Republic of Congo
}

\author{
Jenny C. Aker \\ August 2014
}

\begin{abstract}
Despite recent calls in support of cash transfers, there is little rigorous evidence of the relative impacts of cash versus in-kind transfers, especially in humanitarian contexts, where a majority of such programs take place. This paper uses data from a randomized experiment in the Democratic Republic of Congo to assess the relative impacts and costs of equivalently-valued cash and voucher transfers. The voucher program distorted households' purchases along both the extensive and intensive margin as compared with unconstrained cash households. Yet there were no differences in food consumption or other measures of well-being, in part due to the fact that voucher households were able to resell part of what they purchased. As there were no significant benefits to vouchers, cash transfers were the more cost effective modality for both the implementing agency and program recipients in this context.
\end{abstract}

Keywords: Cash Transfers; In-Kind Transfers; Vouchers; Democratic Republic of Congo, Impact evaluation

JEL classification: J22; O12; C21

\footnotetext{
Jenny C. Aker, Department of Economics and The Fletcher School, Tufts University, 160 Packard Avenue, Medford, MA 02155; Jenny.Aker@tufts.edu. I thank Concern Worldwide in DRC for their support in all stages of this project and would especially like to thank Feargal O'Connell, Gabrielle Smith, Julia Lewis, Kai Matturi, Saul Butters, Joel Tschite and the data collection team in DRC. I greatly appreciate comments from Jessica Goldberg, B. Kelsey Jack, Julie Schaffner and two anonymous referees, as well as participants at the seminar at IFPRI, University of Gottingen, Northeastern Universities Development Conference (NEUDC), Clark University, George Washington University and Tufts University. I am grateful for financial support from Tufts University. All errors are my own.
} 


\section{Introduction}

How should wealth be redistributed to the poor? While cash transfer programs have become an increasingly important part of social protection programs worldwide, a majority of welfare transfers in both developed and developing countries are still in-kind (Tabor 2002, Currie and Gahvari 2008). For example, the U.S. 2013 budget allocated over US\$293 billion to food stamps, Medicaid and housing vouchers, suggesting that the current ratio of U.S. in-kind assistance to cash transfers is 5.6 to 1 (Glaeser 2012). Globally, 92 percent of low-income countries have in-kind transfer programs, whereas 51 percent have a cash transfer program (Gentilini et al 2014). Given that economic theory predicts that a program recipient will at least (weakly) prefer a cash transfer as compared with an equal-valued in-kind transfer or voucher, why would the public sector prefer in-kind transfers? ${ }^{1}$

There are several reasons why in-kind transfers, including vouchers, might be preferred to cash. First, governmental or non-governmental organizations might want to encourage program recipients to purchase and consume particular food or non-food items, which is more difficult with cash transfers (Cunha 2014, Currie and Gahvari 2008). ${ }^{2}$ Second, in-kind transfers may facilitate targeting by encouraging the non-poor to select out of social protection programs (Nichols and Zeckhauser 1982, Moffitt 1983). Third, if certain items are not readily available on local markets, in-kind distributions can increase the local supply of those items. Fourth, in-kind transfers may be more politically viable, especially among populations who are not eligible for the program (De Janvry, Fargeix, and Sadoulet 1991; Epple and Romano 1996). And finally, providing in-kind transfers could be less risky for program recipients, especially if cash is easier to steal.

The relative merits of cash as compared with in-kind transfers have been vigorously debated, particularly in the context of developing countries (Devereux 2006). A 2011 DFID report noted that governments in the developing world are increasingly investing in cash transfer programs (Arnold et al

1 In the economics literature, vouchers are categorized as in-kind transfers, as they are often restricted to the purchase of particular items and can lead to a kinked budget constraint (Whitmore 2002, Currie and Gahvari 2008). Development practitioners and donors often make a distinction between cash transfers, in-kind transfers (free distributions) and vouchers ("near-cash"), as vouchers are more fungible than pure in-kind distributions.

2In addition, if policymakers understand the nutritional implications of food consumption choices better than participants, then such policies could lead to higher "true" well-being (where well-being is defined as participants' preferences under full information or spillovers from improved nutritional status). 
2011). More recently, there have been a number of calls for cash as a "first-best option" (Gentilini 2014, Blattman 2014, Blattman and Niehaus 2014, Ozler 2013).

What is surprising about these calls for cash is the limited rigorous evidence to support these claims (Banerjee et al 2014). While there is extensive literature on the impacts of conditional and unconditional cash transfers, as well as the impacts of in-kind transfers (Whitmore 2002, Hoynes and Schazenbach 2009, Fraker et al 1995, Yen 2010), the empirical evidence of their relative impacts is more limited. ${ }^{3}$ In some cases, that comparison has been affected by differences in program design between the two modalities (Sharma 2006, Cunha 2014, Skoufias et al 2008, Gentilini 2014). ${ }^{4}$

We report the results of a randomized transfer program in the Democratic Republic of Congo (DRC), where internally displaced households living in an informal camp were randomly assigned to cash and voucher transfer modalities. The first intervention, an unconditional cash transfer, was provided in three distributions over a six-month period. The second intervention, an equal-valued voucher, was a coupon that could be redeemed at an organized "voucher fair" selling a variety of food and non-food items for the first transfer, but restricted to food items for the second and third transfers. To minimize the likelihood that any observed differences might be due to differences in program design -- rather than the transfer modality -- the transfer amounts, frequency, conditions and costs of obtaining the transfer were as similar as possible between the two modalities, and prices at the voucher fair were "set" accordingly to local market prices. Given the extreme vulnerability of the target populations, there was no pure comparison group. Thus, our analysis focuses on the relative impacts of the different transfer modalities, rather than the overall impact of the program.

3 There has also been growing evidence on the relative impacts of conditional and unconditional cash transfers (Baird et al 2011, Benhassine et al forthcoming).

4 Sharma (2006) reports the result of a randomized intervention of an equivalently-valued food or cash transfer program in Sri Lanka. Yet the frequency of the two transfer modalities differed considerably. Cunha (2014) reports the results from a randomized cash and food transfer program in southern Mexico (Cunha 2014), where the food transfer was worth 33 percent more than the cash transfer, and the two transfer modalities were provided at different frequencies. WFP and IFPRI have recently conducted a series of randomized evaluations of cash versus food transfers in Uganda and Niger (Hoddindott et al 2014, Gilligan et al 2013), and cash, voucher and food transfers in Ecuador (Hidrobo et al 2014). 
We find that households' purchasing decisions differed significantly by transfer modality. Unsurprisingly, cash households used their transfer to purchase a diverse set of food and non-food items, including paying for health expenses and school fees, and did not appear to buy "temptation" goods (Evans and Popova 2014). Yet voucher households were significantly more likely to purchase particular food items, namely salt, as it was storable and easier to resell. These results suggest that distortions imposed by the voucher were apparent at both the extensive and intensive margins. Yet differences in purchasing decisions did not translate into differences food consumption or asset ownership between the two modalities. As there were no significant differences in household well-being, the cash transfer program was the more cost-effective modality for the implementing agency and program recipients in this context.

Our study most directly relates to the recent work of Hidrobo et al (2014), who assess the relative impacts of food, cash and voucher transfers among Colombian refugees in northern Ecuador. While all three modalities improved the quality and quantity of food consumed, they find that vouchers led to significantly larger increases in dietary diversity. Although both of our studies focus on similar population - displaced households - the design is markedly different, as their intervention offered nutrition sensitization and a more flexible voucher program (e.g., the vouchers could be used twice per month at supermarkets). These "flexible" voucher designs are more common in programs in developed countries or urban voucher programs, but are less common among programs in rural areas or humanitarian contexts, which makes up a significant amount of funding for voucher programs.

The rest of the paper proceeds as follows. Section 2 describes the context in DRC and the experimental design. Section 3 outlines the theoretical framework. Section 4 describes the different datasets and estimation strategy. We discuss the results in terms of uses of the transfer (Section 5) before discussing the mechanisms behind these results (Section 6) and alternative explanations (Section 7). We describe the cost-benefit analysis in Section 8 before concluding.

\section{Setting and Research Design}

\subsection{Conflict and internally displaced populations in eastern DRC}


One of the largest countries in sub-Saharan Africa, the Democratic Republic of Congo has been at the center of what has been termed "Africa's world war" since the late 1990s. The original conflict lasted five years and pitted government forces, supported by Angola, Namibia and Zimbabwe, against rebels backed by Uganda and Rwanda (Williams 2013). The war has claimed an estimated three million lives, either as a direct result of fighting or because of disease and malnutrition (UNICEF 2012).

Despite a peace deal in 2003, renewed fighting erupted in the eastern parts of the country in 2008, displacing millions of people. As of 2011, it was estimated that there were 1.7 million internally displaced persons (IDPs) in the eastern part of the country. The most vulnerable regions are those of North and South Kivu, which are subject to attacks by government and militia forces, looting and sexual violence. IDPs have been forced to move to formal or informal camps (Williams 2013).

Without access to land, livestock or other means of generating income, IDPs are often heavily dependent upon external aid to meet their basic needs. Throughout the conflict, international and nongovernmental organizations have distributed food aid, medicines, agricultural inputs and non-food items (blankets, mattresses, hygiene kits and kitchen sets). More recently, such organizations have also provided cash transfers and vouchers, the latter of which is a type of coupon that enables program recipients to purchase goods at pre-organized fairs.

The focus on vouchers as a component of humanitarian assistance in eastern DRC is not uncommon among international humanitarian programs. Of more than 15 international organizations working in eastern DRC in 2011, over 10 of them provided voucher assistance. Focusing on humanitarian assistance more broadly, over 58 percent of USAID's emergency response program was allocated to in-kind transfers in 2012, with 25 percent of that allocation devoted to vouchers (Hanrahan 2013).

\subsection{Transfer Interventions}

In response to the ongoing conflict in eastern DRC, an international non-governmental organization, Concern Worldwide, designed a short-term social protection program. The program sought to increase households' access to basic food and non-food items and services by providing income transfers to 
474 IDPs and their households living in an informal camp over the course of 2011 and 2012. The bulk of the transfers were provided between September and November 2011, the "hunger months" in eastern DRC. ${ }^{5}$

The first intervention was the cash transfer (cash), whereby households received an unconditional cash transfer of US $\$ 130$ over a seven-month period. The total value of the transfer was approximately $2 / 3$ of the total annual GDP per capita for DRC, similar to the value of other income transfer programs in DRC and other emergency contexts in sub-Saharan Africa (Garcia and Moore 2012). ${ }^{6}$ The payments were made in three disbursements: September 2011 (US\$90); November 2011 (US\$20) and February 2012 (US\$20). The transfer was directly deposited into an interest-free account at the office of a local cooperative located in a nearby town and market center (Masisi Center), so that program recipients had to travel to the town to pick up their transfer. The accounts were opened free of charge, and there were no fees to withdraw the cash transfer.

The second intervention, a voucher, provided program recipients with coupons to spend on any items for sale at pre-organized voucher fairs. The total value of the voucher program was also US\$130, and the timing and amount of the distributions were similar to those of the cash transfer modality. Like the cash transfer, the coupons were distributed at Masisi Center, although on a different day than that of the cash transfer. ${ }^{7}$ For the first distribution, program recipients could spend the voucher on a variety of food and non-food items at the fair, including school fees, non-food items (NFIs), clothing, agricultural inputs and small animals. ${ }^{8}$ The second and third vouchers could be spent only on food items at the fairs, whereby program recipients circulated freely among pre-approved vendors. ${ }^{9}$ Voucher recipients were informed of

5Masisi Territory has a first rainy season between September and December (followed by a harvest) and a second rainy season between March and May (followed by a second harvest). The first transfers coincided with a "hungry period", the period between harvests, when supply was relatively lower and prices relatively higher, especially for IDPs, who are net consumers (Save the Children 2003).

6 The size of unconditional cash transfer programs in sub-Saharan Africa varies considerably, ranging from US\$8 per month in Mali to US\$37 and US\$42 per month in Kenya and Rwanda, respectively (Garcia and Moore 2012). These represent between 20-40 percent of per capita income in those countries.

7 While the cash and voucher transfers were not distributed on the same day, they were distributed within the same week.

8 The fair included 122 vendors and four primary schools in the area. A full list of items available at the multisectoral fair is available upon request. Program recipients could purchase school fees for either the entire year or on a semester basis. School fees were due in September, after the first disbursement.

9 Eleven food vendors were eligible to participate at the second food voucher fair, including sugar, cassava flour, beans, rice, vegetable oil, palm oil, dried fish and salt. The third food voucher fair included 18 food vendors and the 
this policy prior to the start of the program, and were also informed of which items would be allowable at the fair. The voucher fair was closed to all non-voucher recipients. All of the voucher fairs took place at Masisi Center on a pre-arranged non-market day (which coincided with the distribution of the vouchers), and vouchers were not valid after this day. While all items at the voucher fair were available at the local markets, some items were excluded from the voucher fairs, such as meat, doughnuts and beer. The maximum prices for each item at the fair were the same as the prices for the most recent market in Masisi Center. On average, price ranges for food and non-food items were similar at the market and voucher fairs (Table A1), and any price differences were not systematically higher or lower for either modality.

Both the cash and voucher transfers were equivalently-valued, distributed at the same frequency, with the same denomination and at the same location. ${ }^{10}$ Yet as is common in most voucher programs in both developed and developing countries, the voucher intervention constrained households' choices in terms of where, when and how the transfer could be used, potentially increasing their transaction costs. ${ }^{11}$ While the voucher intervention in our setting is similar to that of voucher programs in other humanitarian contexts (ECHO 2013, CaLP 2011), it is more restrictive than voucher programs in developed countries (such as US food stamps) or in non-humanitarian contexts. Thus, our findings will not be generalizable to all voucher programs, but rather to a subset of programs that use a similar type of design. In addition, in the absence of a pure comparison group, we can only estimate the relative impacts of alternative transfer modalities, rather than the overall impact of the social protection program. ${ }^{12}$

\subsection{Experimental Design}

same food items. A comparison of the item availability and discussions with program recipients revealed that almost all items were available at the fair, with the exception of meat and doughnuts.

10 While average household size in the camp was 5.5 members, households ranged from 1 to 11 members. Since the size of the transfer was the same regardless of household size, some households received US\$110 per capita, whereas others received US\$10 per capita.

11 In many voucher programs in humanitarian programs, vouchers can be exchanged on pre-arranged voucher fairs, and are valid for a specific period (usually 1-3 days) for specific goods available at the fair (CaLP 2011).

12The purpose of the study was to determine which transfer modality would be the most effective for Concern to assist IDPs. In previous evaluations of Concern's voucher and cash-for-work (CFW) programs, which were implemented separately, Concern received somewhat contradictory evidence: One study of Concern's voucher program reported that women preferred vouchers because cash would be " controlled by their husbands, potentially wasted and put them at risk of theft." (ODI 2009) Yet another study of Concern's CFW program reported that very few program recipients engaged in "irresponsible spending." (MDF 2009). Thus, Concern felt that the idea of "responsible and irresponsible spending" as well as issues around security of cash transfers, deserved further consideration. 
Prior to the intervention, Concern Worldwide identified 474 internally displaced households living in one informal camp in the Masisi territory of DRC, with a total population of approximately 2,500 individuals. All 474 households residing in the camp were eligible for the intervention, and there were no other international organizations providing aid within the camp. Households were first stratified by neighborhood and then randomly assigned to either the cash or voucher intervention. In all, 237 households were randomly assigned to the cash transfer intervention and 237 were randomly assigned to the voucher intervention. The transfer was primarily provided to the female household member (either the head of household or the spouse of the household head). ${ }^{13}$ While it would have been optimal to ensure a minimum distance between households assigned to different transfer modalities in order to minimize spillovers, this was not possible. The study timeline is presented in Figure 1.

\section{Theoretical Predictions}

\subsection{Demand and Welfare under Cash and Vouchers}

While the cash and voucher transfers were designed to be as similar as possible, the impact of the transfer on household demand depends upon the household type and transfer value. If the value of the food voucher is less than what the household would have spent otherwise on food, then the marginal effect of the voucher on demand would be no different from the effect of the cash transfer. ${ }^{14}$ If, however, the value of the food voucher is greater than what the household would have spent otherwise on food, and assuming no resale is possible, then the marginal effect of the voucher program would be different from that of the cash transfer, since the voucher constrains the program recipient's choice.

More formally, assume that households have preferences over two goods, a composite consumption good and food, the latter of which is targeted by in-kind transfers (Currie and Gahvari 2008). Pre-transfer, the household has income $Y$ and each good has fixed prices (Figure 2), and the consumer will maximize utility at points $A$ or $B$. A lump sum cash transfer will cause a shift out of the budget line, whereas an equal-valued food voucher will lead to a kinked budget constraint. If the value of the transfer is infra-

13 In the voucher group, 99.2 percent of program recipients were women. For the cash group, all of the program recipients were women.

14This is true only if the assumptions underlying basic unitary consumer choice theory hold. 
marginal for the household, then the household will reach the same indifference curve regardless of the transfer type, and the voucher is equivalent to cash ( $B$ to $\left.B^{\prime}\right)$. If the value of the transfer is extra-marginal for the household, and frictionless resale is not possible, then the household would prefer to consume at

$$
A^{\prime} \text { but is constrained to } A^{\prime \prime} \text {, and the household prefers cash. }{ }^{15} \text { This simple, two-good model }
$$

predicts that the quantities demanded of will be the same under both transfer modalities if the voucher is infra-marginal, but that the quantity demanded of food will be higher with vouchers if the voucher is extramarginal.

Extending this model to our context is relatively straightforward. While the voucher transfer could be spent on food and non-food items during the first transfer, it was constrained to food items during the last two transfers. Thus, we would expect that the purchasing decisions of cash and voucher households would differ for the last two purchases if the voucher is extra-marginal, at least for a subset of households. Since the vouchers could only be spent at a pre-arranged location for one day, this timing constraint might further distort voucher households' purchases, perhaps towards food items that can be more easily stored, transported or resold. However, the theoretical predictions with respect to the types of goods purchased are ambiguous. ${ }^{16}$

\subsection{Why use vouchers in eastern DRC?}

Despite the potential welfare loss for voucher program recipients, providing vouchers may be preferred public policy in a context such as DRC or other humanitarian contexts. Among the potential reasons cited in favor of in-kind transfers, three appear to be of primary importance in the DRC context. First, while many agencies switched from pure in-kind transfers (e.g., distributions) to vouchers, studies of those programs cited concerns about the consumption of "temptation" goods associated with cash transfers (UNICEF 2012, ODI 2009). Since voucher recipients in our study were prohibited from purchasing certain food items at the voucher fairs (such as meat, doughnuts or beer), this suggests that there might have been

15If resale is allowed, this will rotate the kink in the budget constraint and allow households to reach a higher indifference curve.

16Bazzi et al (2013) show that the timing and expectations of transfers matter. In our context, the timing of the transfers was the same for both modalities. Since both cash and voucher transfer recipients were informed prior to the program that they would receive three transfers, program recipients should have been able to maximize expenditures subject to these respective constraints, although we do not have the data to address this potential issue. 
an implicit preference for encouraging households to purchase and consume particular food items. Second, international organizations were concerned that local markets did not "offer a wide selection of the goods beneficiaries needed", suggesting that vouchers were provided, at least in part, to address these concerns (UNICEF 2012). Finally, vouchers were considered to be safer than cash transfers, as they limited the risks associated with transporting and distributing cash.

\section{Data and Empirical Strategy}

The data we use in this paper come from three primary sources. First, we conducted several rounds of household surveys and use these surveys to measure the impact of the program on households' behavior and outcomes. Second, we collected price data from voucher fairs and markets to measure the value of household asset purchases, as well as the prices that program recipients' faced. Finally, we complement these data with information from focus group surveys with different actors involved in, and affected by, the program. Before presenting our estimation strategy, we discuss each of these data sources in detail.

\subsection{Data}

\section{Household Data}

The first dataset is a household survey of 253 program recipient households. Among the 474 eligible program recipients, we stratified by neighborhood and randomly selected 253 program recipients to participate in the household survey. The baseline survey was conducted in August/September 2011, prior to the distribution of the first transfer, with follow-up surveys in November 2011 (after the second transfer) and March 2012 (after the third transfer). The household survey included modules on household demographics, asset ownership, shocks, income-generating activities and food expenditures. For the follow-up surveys, we also included modules on the uses of the cash transfer or voucher. As female program recipients primarily worked as laborers or transporters for non-IDP households, with relatively long distances of travel, we were mindful of the time burden on respondents. As a result, the household surveys did not include a full income and expenditure module. While this somewhat constrains our analysis, as we argue below, we feel that data on the uses of the transfer approximates households' expenditures. 
Typically, attrition is a concern in any humanitarian context, as violence is frequent and populations are highly mobile. Immediately prior to the second round of the survey, violence intensified in the area, and approximately half of the IDP households fled into the surrounding hills. While over 75 percent of households were present in the camp during the third survey round, attrition raises concerns about the external and internal validity of our findings. If the types of households who stayed were different from those who fled, this further affects the external validity of the findings. Or, if the characteristics of the remaining households differed between the voucher and cash groups, then this could affect the internal validity of our findings despite the randomized design. ${ }^{17}$

Table A2 formally tests whether there is differential attrition at different rounds of data collection. While 44 percent of households were missing in November 2011 (the second round), there was not a statistically significant difference in attrition rates between the cash and voucher households (Panel A). Attrition in March 2012 (the third round) was significantly lower, with 23 percent of households missing. Similar to the November 2011 round, there was no statistically significant difference between the two groups. We also test for whether the baseline characteristics among non-attriters - namely, those respondents present during the third survey round - differ by treatment modality (Table 1, Columns 5-8). There are no statistically significant differences between cash and voucher households who stayed in the sample during the third round, with the exception of the months of adequate household provisioning.

While these results suggest that there is non-differential attrition, we might simply be underpowered to detect an effect. Table A3 thus shows the determinants of drop-out. Overall, baseline characteristics do not individually or jointly predict attrition in the third survey round. The sole exception is marital status: Married respondents were more likely to drop out, suggesting that perhaps single parents were unable to leave. Overall, however, these results suggest that potential bias due to non-random attrition is less of a concern, and that attrition was primarily driven by the random violence and attacks prevalent in the region, rather than individual household characteristics or the transfer modality. Nevertheless, we construct Lee bounds for the core outcomes as a robustness check.

17For example, cash households might have been able to take the cash with them, as compared with voucher households, who would have needed to transport (or sell) goods. 


\section{Price Data}

The second dataset is comprised of price data and price and product information from both the voucher fairs and the primary local market in the area (where the voucher fair was also held). This dataset includes prices for over 25 food and non-food products between September 2011 and March 2012. These data are used to construct measures for the value of assets owned, as well as to determine whether households faced different prices for the same goods on local markets or the voucher fairs. ${ }^{18}$

\section{Qualitative Data}

The household surveys and administrative data are complemented by qualitative data from focus groups with men, women, market resource persons, school principals and the camp administration in March 2012, after the final transfer. The focus groups asked open-ended questions about how households used the transfer and difficulties with the program. These data are used to provide additional insights into the quantitative findings.

\subsection{Pre-Program Balance of Program Recipients}

Table 1 suggests that the randomization was successful in creating comparable groups along observable dimensions. Differences in pre-program socio-demographic characteristics are small and insignificant (Panel A, Column 3). Average household size was five. All of program recipients in our sample were women, a majority of whom were married. Households had, on average, been living in the camp for 1.5 years.

Panels B-E provide further evidence of the comparability of the cash and voucher households for a variety of outcomes. It is crucial to note how vulnerable these households were: Households had very few income-generating opportunities, relying upon only 1.7 sources of income, primarily daily wage laborers or transporters. Income in the previous week was 2400 Congolese Francs (US\$2.50), and households spent approximately 70 percent of their income on food. There were also few differences in food security status

18The voucher fair data also include information on what voucher households purchased, the quantity purchased and the price paid, although we do not have corresponding data for the cash households. We also have data on cash transfer households' accounts with Cooperative Bwira, the Cooperative that distributed the cash transfer. The dataset includes information on the date of the transfer, the day of the receipt of the transfer, the amount withdrawn and any savings in the account. 
between the two groups prior to the program (Panel E). The average household diet diversity score (HDDS) was 2.90 (out of a total of 12 food categories), well below the average HDDS in sub-Saharan Africa (4) and the recommended HDDS (6). ${ }^{19}$ Households and children ate an average of 1.29 meals in the past 24 hours. The only statistically significant difference among the food security indicators was for the months of adequate household provisioning: on average, cash households reporting having had "enough food" for .19 more months than voucher households. Overall, the results in Table 1 are robust to conducting Kalmogorov-Smirnov tests (Column 4). We also find similar results when restricting the sample to non-arriters from third survey round (Columns 5-8).

\subsection{Estimation Strategy}

To estimate the effects of different transfer modalities on a variety of outcomes, we use a regression specification that takes the following form:

$$
Y_{i}=\gamma+\alpha \operatorname{cash}_{i}+\mathbf{X}^{\prime}{ }_{i 0} \gamma+\theta_{N}+\varepsilon_{i}
$$

The variable $Y_{i}$ represents the outcome of interest (uses of the transfer, purchases, food expenditures, food security and assets) of household $i$ after the transfer. $c a s h_{\mathrm{i}}$ is an indicator variable equal to one if the household was assigned to an unconditional cash transfer, zero if the household received the voucher. $\theta_{N}$ are neighborhood fixed effects, the level at which we stratified the randomization. To improve precision, we include a vector of household baseline covariates, $\mathbf{X}_{i v 0}$, primarily the quadratic of household size. ${ }^{20}$ The error term consists of $\varepsilon_{i}$, which captures unobserved individual or household characteristics or idiosyncratic shocks. The coefficient of interest is $\alpha$, the intent-to-treat (ITT) effect of the cash transfer (as compared with the voucher) on the outcome of interest, under the assumption that $c a s h_{i}$ is orthogonal to $\varepsilon_{i}$. Since take-up was nearly perfect, the ITT is equivalent to the average treatment effect on the treated (ATT).

19The HDDS is a 24-hour recall measure of diet diversity. The instrument involves interviewing the person responsible for preparing meals within the household and asking if anyone in the household consumed each of the 12 different food categories, including grains, tubers, beans, fruits, vegetables, meat, fish, eggs, oils, sugar and condiments (including salt). The indicator ranges from 0 to 12, with 12 the highest degree of diet diversity (FANTA 2006).

20Including household size in the regression also ensures that we are not capturing the effect for a subset of the population, e.g., small households whose per capita value of the transfer was much higher than larger households. Results are robust to excluding household size. 
Given the high rate of attrition in the second survey round, we use the data from the third survey round for all specifications. However, we also present the results using the pooled data across all survey rounds (Table A4).

Equation (1) is our preferred specification for most outcomes, as much of the data were not collected during the baseline. For those outcomes where baseline data are available, we also estimate the treatment effect using the Analysis of Covariance (ANCOVA), which controls for baseline values of the outcome variables. In cases where the outcome variables have high variability and low autocorrelation, as is the case in our context, the ANCOVA model is preferred over difference-in-differences (McKenzie 2012).

As is the case with unconditional cash transfer programs, there are a number of potential causal pathways. Throughout this paper, we examined the impact of the transfer modality on over 60 different outcomes. This raises concerns that the observed effects cannot be attributed to the transfer modality, but are rather simply observed by chance. We address this issue by using a Bonferroni correction that adjusts for the mean correlation among outcomes (Sankoh et al 1997). ${ }^{21}$ In each table, we report the standard pvalue, as well as the p-value adjusted for multiple hypothesis-testing. ${ }^{22}$

\section{Results}

\subsection{Extra-Marginality of the Transfer \\ Extensive Margin of Overprovision and Uses of the Transfer}

According to our theoretical predictions, we would only expect to see differences in household purchases between the two transfer modalities if the value of the transfer was extra-marginal for a subset of households. Figure 3 shows the cumulative density function of pre-transfer weekly household food expenditures for the cash transfer group. With a voucher transfer equal in value to $2400 \mathrm{FC}$ per household per week (US\$2.62) for the last two transfers, only about 20 percent of households would have consumed more than this amount on a weekly basis. This suggests that that value of the food voucher was extra-

21In the case of correlated outcome variables, the mean correlation between outcome variables can be included as a parameter in the Bonferroni adjustment (Sankoh et al 1997). A mean correlation of zero would yield the full Bonferroni adjustment, whereas a mean correlation of one would mean no adjustment.

22 As households within the same neighborhood might be correlated, we would normally cluster observations by neighborhood. However, there are only eight neighborhoods within the camp. As the Huber-White standard errors may be misleading in this case, as a robustness check, we also conduct inference using a variant of the non-parametric permutation test (Efron and Tibshirani 1993, Anderson 2008) and find similar results (not shown). 
marginal for a significant portion of households in the sample, and hence that there might be differences in the quantities demanded between the two modalities. ${ }^{23}$

As we do not have a full expenditure module, or the quantities purchased of all food and non-food items, we are unable to show the impact of the transfer on total expenditures or the quantities demanded of all food and non-food items. Nevertheless, we do have data on the uses of the transfer and the amount spent on a subset of food and non-food items. While this constrains our analysis, we feel that these outcomes are useful for two reasons. First, the transfer represented a significant income shock to recipient households, equivalent to one week of pre-transfer household income. Given this fact, as well as the fact that households only had 1.7 income sources (prior to the program) and did not receive external aid from other international organizations, it is reasonable to assume that households' marginal propensity to consume was high, and that the uses of the transfer would approximate overall expenditures during this period. ${ }^{24}$ Second, as program recipients faced similar prices at the market or voucher fair (Table A1) and there were no reported stock-outs for the last transfer (other than intended "forbidden items"), the uses of the transfer capture voucher households' decision-making under constrained choice. ${ }^{25}$

As the cash transfer was unconditional, program recipients were free to spend the transfer how they wished. Focusing on the last transfer, cash households used their transfer to purchase 6.98 different categories of goods (out of a total of 25 categories), including food items (staple and other grains, beans, oil, meat, salt and fish), clothing and school fees (Table 2). (Respondents could list more than one use of the cash transfer, so the total can exceed $100 \%$.) Fewer than 1 percent of households used the cash transfer

23This calculation assumes that weekly food expenditures remained relatively constant over the course of the program. While this is a simplifying assumption, it provides a benchmark of comparison for understanding the potential extra- or infra-marginality of the voucher transfer. In addition, although the value of the transfer could have been extra-marginal for most program recipients, it would have been infra-marginal for the wealthiest households (as the maximum amount spent on food prior to the program was $48000 \mathrm{FC}$, or US\$48).

24Pre-program food expenditures suggests that over 70 percent of income was spent on food, so that households were likely near subsistence constraints and had a high marginal utility of income.

25Understanding how voucher households optimize under such constraints, which is partially captured by the uses of the transfer, is often not measured in other cash versus in-kind transfer research. For example, Cunha (2014) and Hoddinott et al (2014) assess the impacts of a food versus cash-transfer program, and so cannot observe the purchasing decisions of food transfer households (as they were provided directly with food). Rather, they focus on the impact of the program on the quantities consumed and diet diversity. Hidrobo et al (2014) primarily focus on comparing the value of food consumption among cash, voucher and food households, rather than their purchasing patterns. While useful, this does not necessarily provide insights into the ways in which the voucher program constrained households' choices. 
to buy "temptation goods", defined in this context as doughnuts and beer. ${ }^{26}$ Thus, cash transfer recipients primarily used the transfer to ensure immediate consumption needs, but also to invest in non-food items and their children's education. ${ }^{27}$

As compared with voucher households, cash households used their transfer to purchase a more diverse set of food and non-food items (Panel A, Column 2). Focusing on food items, cash program recipients were significantly more likely to purchase staple grains (a 24 percentage point increase), beans (a 38 percentage point increase), condiments (a 26 percentage point increase) as well as oil, meat and vegetables as compared to the voucher group (Panel A). Of these items, only meat was not available at the voucher fair. For non-food items, cash households were significantly more likely to use the transfer to pay for school fees, buy medicines, reimburse debts, and purchase clothing and housing materials as compared with voucher households (Panels C and D) ${ }^{28}$ These differences in non-food purchasing patterns are not surprising, as these items were not available to voucher households for the last two transfers. Nevertheless, this pattern is similar across all transfers (Table A4).

While cash households were more likely to purchase a more diverse set of food and non-food items, the voucher modality distorted the purchasing decisions of voucher households for specific food items. Voucher households were 10 percentage points more likely to purchase other grains (namely rice) and 13 percentage points more likely to purchase salt than cash recipients, although only salt is statistically significant at the 5 percent level (Table 2, Column 2). These patterns were also similar across all transfers (Table A4).

Intensive Margin of Overprovision and Food Expenditures

26 It is possible that we observe no consumption of temptation goods because households were afraid to report the consumption of these goods. While we cannot rule out this possibility, we are primarily concerned with differential spending on temptation goods between the two modalities, rather than the spending on temptation goods per se. This is in line with evidence from other cash transfer programs (Evans and Popova 2014).

27 A potential concern with this measure is that program recipients could simply list the first or largest expenditures made after receiving the transfer, which could differ by treatment groups. Thus, we might see a treatment effect on measured expenditures rather than actual expenditures. This concern is alleviated by the way in which the question was administered: after program recipients listed their initial categories, enumerators were instructed to go through a comprehensive list of potential categories and ask the recipient if they used the transfer on that particular category. 28Two cash households used money from all three transfers top purchase a parcel of land. 
While Table 2 shows the extensive margin of overprovision for each food item, we might be interested in the intensive margin of the uses of the transfer. Given the high degree of measurement error related to the amounts purchased, as well as the limited time for surveys, we only collected expenditure data (related to the transfer) for a subset of food categories. While the data do not represent the entire allocation of the transfer, they do provide some insights into the extent of the intensive margin of overprovision for voucher households. ${ }^{29}$ Consistent with the results in Table 2, voucher households spent more on salt, fish and other grains than cash households, although only the difference for salt is statistically significant at conventional levels (Panel B). Yet the magnitude of the salt purchases is significant: Whereas cash households spent approximately US\$ .78 on salt (or $2.5 \mathrm{~kg}$ at local market prices), voucher households spent US\$ 8.36 , or a $25-\mathrm{kg}$ box of salt. This is supported by qualitative data, as voucher households stated that they purchased salt specifically for the purposes of resale, as well as the fact that it could be easily stored. In fact, the results in Table 3 suggest that voucher households might have allocated some of their transfer away from some food items in order to purchase the $25-\mathrm{kg}$ bag of salt, as salt was sold either in small sachets or $25-\mathrm{kg}$ boxes.

While Table 3 (Panel A) looks at transfer expenditures, Panel B assesses whether total weekly food expenditures differed by transfer modality. ${ }^{30}$ Overall, cash households spent approximately US\$ .34 less than voucher households on food, or about US\$ .11 less per capita, although these differences are not statistically significant (Column 2). As the expenditure data are highly skewed, and we have some zero values, we use an inverse hyperbolic sine transformation (Burbidge et al 1998). Using the non-linear specification, we find that cash households spent 9-17 percent less on food than voucher households (per capita and overall, respectively), although it is not statistically significant. While these effects are small in absolute terms, this is consistent with the pattern of cash households spending slightly more on a variety of

29On average, voucher households spent approximately US\$17 on food items listed compared with the US\$20 voucher value (Panel A, Column 1). Cash households spent approximately $\$ 13.5$ on the listed food items, suggesting that they had $\$ 6.50$ to spend on other food and non-food items. At local market prices, the additional quantities purchased by cash transfer households would not have been significant (ranging from $1 / 3 \mathrm{~kg}$ of flour, beans or meat, or .6 liters of oil).

30 Given that our expenditure data are highly skewed, and we have a number of zero values, we use an inverse hyberbolic sine (IHS) transformation to transform the food expenditure data (Burbidge et al 1998). 
different food items, as compared with the voucher households' spending significantly more on one primary food item: salt. ${ }^{31}$ These results are also robust to using an ANCOVA specification (Table A5).

Overall, these results suggest that distortions imposed by the voucher are apparent at two margins. First, voucher households purchased some categories of goods at significantly higher rates than cash households. Second, voucher households adjusted at the intensive margin, purchasing more of some goods (primarily salt) than the unconstrained cash households chose.

\subsection{Food Consumption and Assets}

Since the voucher program distorted voucher households' purchasing decisions as compared with the cash transfer, a natural question is whether the transfer modality had differential effects on other aspects of well-being. For example, if voucher households incurred significant costs while reselling salt, the value of the transfer could have been significantly lower among voucher households, thereby lowering their purchasing power. In addition, since cash households were able to use the transfer when, where and how they wished, they could have saved a portion of the transfer, thereby allowing them to better cope with shocks; or they could have arbitraged for better prices across different markets, thereby increasing their purchasing power as compared with voucher households. ${ }^{32}$ Since cash households purchased a more diverse set of food items, albeit in relatively small quantities, it is possible that this could have translated into better outcomes.

Table 4 looks at the impact of the transfer modality on households' food consumption, as measured by diet diversity, the number of meals per day and the number of months of adequate provisioning. Using the HDDS, voucher households consumed 3.09 food categories, without a statistically significant difference between the two modalities (Panel A). ${ }^{33}$ There also were no statistically significant differences in

31An alternative explanation is that cash households bought most of their food with the cash transfer, and thereby lowered their food expenditures in the weeks following the transfer. As voucher households had to sell the salt to generate income and purchase food, their expenses might be slightly higher.

32If one of the objectives of the voucher program was to encourage greater consumption of food items, these benefits would be mitigated to the extent that households purchased items that were not oriented towards consumption or did not consume what was provided. Resale of the goods would detract from the objective of increasing the consumption of those specific foods, whereas lumpy expenditures would supports this objective.

33A more varied diet is associated with a number of improved outcomes in areas such as micronutrient intake, birthweight (Rao et. al. 2001) child anthropometric status (e.g., Hatloy et al, 2000) and food expenditures (Hoddinott and Yohannes 2001). 
likelihood of consuming particular food groups, or on other food security indicators, including the number of meals per day and the number of months of adequate food provisioning (Panel B). ${ }^{34}$ These results are also robust to using data from all transfer periods (Table A4), as well as controlling for baseline values in an ANCOVA specification (Table A5).

Panel C presents the results of equation (1) for a variety of proxy measures for well-being, including income, assets and negative coping strategies. Consistent with the results in Panels A and B, there is little evidence that the transfer modality led to differential improvements in well-being. There are no statistically significant differences for income, the value of assets owned or the use of negative coping strategies to deal with shocks, as measured by a Coping Strategy Index (Maxwell and Caldwell 2008). ${ }^{35}$ The one difference is money left over from the transfer, as broadly defined: Cash households were 7 percentage points more likely to have cash left over from the transfer as compared with voucher households, with approximately US\$1.11 remaining. These results are statistically significant at the 5 percent level. While voucher households did not report having cash left over from the transfer, they were 7 percentage points were more likely to have poultry (available at the first voucher fair), although the effect is not statistically significant. This suggests that cash and voucher households engaged in different, but equivalent, types of savings from the transfer. These results are also robust to an ANCOVA specification (Table A5). ${ }^{36}$

\section{How did the voucher design affect households' behavior?}

The core result of this paper is that receiving a voucher transfer, as compared with an unconditional cash transfer, led to significantly different uses of the transfer, and the significant overprovision of one food commodity for voucher households. Yet these differences did not lead to differential diet diversity or asset

34 While milk is included as a category in HDDS, no voucher or cash households consumed milk, so it is excluded. 35Over 86 percent of households in the Bushani camp suffered at least one shock between September and March, primarily illness (54\%), the death of a household member (9\%), increased local prices (19\%) and conflict (57\%). Households used a variety of different coping strategies to deal with these shocks, including reducing diet diversity and rationing food, selling off assets or taking children out of school.

36We might expect differential effects on purchasing patterns, food security and other measures of well-being by certain characteristics. We test for differences in these outcomes by household size, marital status and baseline food expenditures (Table A6). Overall, the results show that the effect of the transfer modality did not differ by household size, marital status or baseline food expenditures. 
ownership. This section presents evidence as to how the voucher design affected both purchasing decisions and outcomes.

\subsection{Why did voucher and cash households make different purchases?}

There are multiple mechanisms through which the design of the program might have affected voucher households' purchasing decisions. First, while Concern Worldwide tried to identify an exhaustive list of program recipients' preferences beforehand, and worked hard to ensure that those food and non-food items were available at the voucher fairs, some items were forbidden (such as meat or doughnuts), thereby affecting voucher recipients' choices. Second, while cash households could spend the transfer where, how and when they wished, voucher households had to use the entire value of the voucher on the day of the fair and for specific food items, thereby affecting their choices. ${ }^{37}$ And finally, as the transfer program primarily targeted women within the household, the transfer modality could have affected women's control over purchasing decisions. ${ }^{38}$

Table 5 shows how the in-kind transfer design might have affected households' purchasing decisions. Unsurprisingly, all of the voucher households used their transfer at the voucher fairs, whereas none of the cash households did so (not shown). Cash households were 98 percentage points more likely to spend the transfer at one of the markets outside of the camp, either at the primary market where they received the transfer or a market that was closer to the camp, but in a less secure zone. ${ }^{39}$ In terms of the timing of the transfer, none of the voucher households used their transfer over multiple periods (by design), whereas

37Concern Worldwide collected price data on the key regional market prior to the voucher fair and used these prices as the maximum prices for goods at voucher fairs. Table A1 shows that voucher households did not face substantially different prices at the voucher fairs (as compared with market prices); nevertheless, the program design might have affected program recipients' ability to bargain for a lower price. In fact, voucher program recipients noted that traders often first cited the maximum price on the market.

38An additional reason for the differences in purchasing patterns might have been "decision fatigue". While most economic models are based on the assumption that agents are unconstrained in their ability to process information, people often use simple cognitive shortcuts when processing information, leading to systematic biases in decision making (Simon 1955, Lacetera et al 2012). While voucher households were informed in advance of the availability of items on voucher fairs, and in theory should have been able to plan their choices well in advance, this information might not have been easily processed.

39There were only three markets within a $20 \mathrm{~km}$ radius of the camp, Masisi, Lumumbashi and Nyabiondo, although only Masisi and Nyabiondo were frequented by camp residents. 
cash households were 80 percentage points more likely to use the transfer over multiple periods (Panel B).

All of these effects are statistically significant at the 1 percent level.

While the transfer modality affected where, when and how program recipients spent the transfer, it did not appear to strongly affect intra-household decision-making with respect to the transfer (Panel B). A majority of voucher program recipients reported that they were responsible for spending all or part of the transfer, along with their husbands. Yet female program recipients in voucher households were 14 percentage points less likely to discuss the use of the transfer in advance with other family members, with a statistically significant effect at the 5 percent level. Whether this was due to limited information about the types of goods available at the fair or reflects greater decision-making power in voucher households is unclear. However, all other indicators related to intra-household decision-making are not statistically significant at conventional levels.

The results in Table 5 thus suggest that the voucher program functioned as designed: voucher households had to spend their transfer all at once and at the voucher fair, and did not have unrestricted choice. This design naturally affected what households purchased, including considerations about arranging the transport, storage and resale. ${ }^{40}$

\subsection{Why was well-being the same in voucher and cash households?}

Despite the fact that the voucher modality led to different purchasing decisions between voucher and cash households, there were no differences in food security or asset ownership. Why was this the case? The most likely explanation is that the transfers were non-binding; in other words, voucher households could sell the goods that they purchased or share some of these goods with other households, whereas cash households could share some of their cash. Alternatively, if an underground market for vouchers existed, voucher recipients could have sold their voucher. ${ }^{41}$ In addition, since the food security data were collected

40As transport from the voucher fair to the camp cost US\$5 per trip, program recipients stated that weight was a consideration in deciding what to purchase. For example, 65 percent of voucher recipients traveled with family members to the fair in order to help with transport. Those who were unable to travel with family members either purchased fewer items or smaller items that could be easily carried. As one voucher program participant mentioned, "If something was too heavy, I didn't buy it...I wanted to buy two boxes of salt but could only carry one, so I bought one plus other things."

41 While the sale of vouchers was technically prohibited, some program recipients reported exchanging their voucher for cash, potentially resulting in a lower income transfer to the household. Although it is impossible to gauge the 
three weeks after each transfer, the absence of differences could be due to resale, storage or lumpy expenditures. ${ }^{42}$ Finally, the transfer modality could have affected intra-household decision-making, thereby affecting welfare outcomes.

Table 5 (Panels C and D) looks at the impact of the transfer modality on these different aspects. Unsurprisingly, program recipients shared part of the transfer: while cash households were 13 percentage

points more likely to share the transfer money received with other households, voucher households were 18 percentage points more likely to share goods purchased with the transfer (Panel C). These differences are statistically significant at the 10 and 5 percent levels, respectively. This suggests that sharing is an important household coping mechanism within the camp.

While the transfer modality could have affected intra-household decision-making and hence welfare outcomes, this does not appear to be the case: Overall, men and women made joint decisions with respect to children's education, inter-household sharing and savings (Panel D) ${ }^{43}$, and the patterns of intra-household decision-making did not differ by transfer modality. Thus, the results in Table 5 suggest that the primary factor explaining similar outcomes was the fact that the transfers were non-binding.

\section{Ruling Out Alternative Explanations}

There are several threats to our identification strategy. The primary threat is differential attrition, either related to illness, death or moving. ${ }^{44}$ While Tables A2 and A3 suggest that attrition was plausibly random, baseline marital status was a determinant of attrition in the third survey round. Thus, as a robustness check, we construct Lee bounds (2009) for the primary results for which there are statistically significant findings (Table A7). Overall, the results are robust to bounding the treatment effect.

frequency with which this practice occurred, voucher recipients reported that they could exchange their US\$20 voucher for approximately US $\$ 11.25$-US $\$ 14.15$ at the fair. This suggests that vouchers traded for about 55-70 percent of their face value.

42 However, as our survey asked about assets currently in the household, we believe that the storage story is unlikely. 43Decision-making within the camp might differ from the decision-making structure within program recipients' home villages. In addition, since these questions were asked about spousal decision-making, the questions were only asked of those program recipients who were married or had a partner, thereby further reducing the number of observations in Panel D to 133 households.

44 Since cash households were more likely to spend their transfer on medicines, this could have reduced the likelihood of illness or death among that group. Table 8 (Panel B) suggests that this is not the case, as the prevalence of illness and deaths was similar between the two groups. 
A second threat to the identification of our results is differential take-up. For example, if the cash transfer made it easier for corrupt agents to steal the transfer, then we would observe differential compliance between the cash and voucher households. Or, if households felt more stigmatized by participating in a voucher program, they might have refused assistance. ${ }^{45}$ Table 6 shows the likelihood that a household received the transfer, as well as the amount of the transfer received. All households received their last transfer, regardless of the modality (Panel A). Households received an average of 18,329 FC for the third transfer, slightly less than the value of the transfer. While cash households reported that they received a higher amount - 36 Congolese Francs more, or $\$ .02$ - the magnitude is small, and this is only statistically significant at the 10 percent level. Thus, it is unclear whether the difference in reported versus actual amounts was due to measurement error (it was easier to recall the amount received), leakage in the program or accounting for the potential sale of vouchers.

A third threat to the validity of our findings is spillovers. An optimal research design would have conducted the randomization at the camp level or randomized at the camp neighborhood level, ensuring a minimum distance between neighborhoods (or households within the neighborhood). While all of these designs were considered at length, there were insufficient sampling units, as well as concerns that a neighborhood-level randomization might be construed as "targeting" certain households within the camp. Thus, our identifying assumption fails if, because of spillovers, the cash transfer group is not a proper counterfactual for how households in the voucher group would have behaved if they were provided with the cash transfer. ${ }^{46}$

Since we cannot rule out the likelihood of spillovers between the two groups - and in fact, evidence in Table 5 points to inter-household sharing - we argue that spillovers do not invalidate our findings. First,

45 Imperfect compliance in this context was minimal, potentially for two reasons. First, adverse stigma effects associated with participation (as in Moffitt 1983) are unlikely in this context where all households in the camp were provided with some type of assistance. Second, households were required to present beneficiary identification cards to receive aid packages and program recipients had to travel to Masisi Center to receive the cash or voucher, making it unlikely that ineligible households in fact received aid.

46 In addition to this direct spillover effect, we might also be worried about a direct behavioral effect if voucher households changed their behavior as a result of knowing that other households had been offered cash, similar to a John Henry effect. Alternatively, voucher households could have strategically purchased more of non-food items during the first round and more food items during the second and third rounds. Looking at the first transfer, voucher households were not more likely to use the transfer for non-food items than cash households. 
the issue of inter-group sharing is unlikely to have affected household purchasing decisions, especially for voucher households, as they had to purchase their items at the fair on the same day (and could not share their vouchers with other households at the fair). While cash households could have shared some of their cash with voucher households, thereby affecting voucher households' purchasing decisions, this would have made it more difficult for us to detect differences in purchasing patterns between the two groups. This is supported by the data: If we estimate the regressions only for the subset of our sample that reported that they did not share cash or goods, we find similar results.

A fourth alternative explanation is the effect of different transfer modalities on prices (Cunha et al 2013). If the cash transfer put greater inflationary pressure on local markets, this could have reduced the value of the transfer for those households. Or, if voucher households were faced with higher prices on the voucher fairs, particularly if traders exerted some degree of market power, then this could have reduced the purchasing power of voucher households. While the data in Table A1 suggest that the two groups did not face differential prices at the voucher fair or market, we do not have price data for all three markets within the area. Yet the overall magnitude of the transfer program in the area was fairly small, with a target of 474 households and US\$30,000 over a seven-month period, as compared with an IDP population of 60,000 . In addition, cash households purchased in markets that were 15-20 km apart over several weeks, with fairly limited integration between these markets. This suggests that differential impacts on prices are not driving our results. $^{47}$

\section{Costs and Security}

One of the key reasons for using vouchers in eastern DRC was to ensure that households could get access to the goods they preferred. Yet the previous results suggest that cash households were able to purchase a wide variety of food and non-food items, and that there were not differential impacts on household food security and asset ownership. Given these results, what were the costs?

47A final threat to the validity of our findings is response bias, ie, if cash and voucher households reported differentially, thereby leading to non-classical measurement error. While we cannot directly test for this, we do look at whether the transfer modality affected a variable that should not have been affected by the program during this time period: household size. While an imperfect proxy, we do not find statistically significant differences in household size between the transfer modalities during the second or third survey rounds. 
Figure 4 shows the per recipient cost of each transfer modality. These costs include the staff time, materials, and security, travel and account and transfer fees (primarily for the cash transfer). When looking at the costs per program recipient, the voucher program cost US\$14.35 (per recipient), whereas the cash program cost US\$11.34 (per recipient), about US\$3 cheaper per program recipient. Overall, the cost breakdown shows that staff time represents the largest percentage of costs for both interventions, followed by transport and voucher printing (for the voucher intervention) and account-opening fees (for the cash intervention). Yet since the account-opening fees are a one-time, fixed cost, if Concern were to continue cash transfers with existing beneficiaries, the cost per cash program recipient would have only been US\$6 or US\$8 less expensive than vouchers - per program recipient.

While the cash transfer program was less expensive for the implementing agency, an important question is whether the two transfer modalities were similar in terms of their costs to program recipients. For both the cash and voucher program, program recipients had to travel $20 \mathrm{~km}$ to obtain their transfer, a significant time cost for program recipients (over three hours). In terms of waiting time, the average waiting time was 1 hour and 45 minutes, while the wait time for voucher recipients was 1 hour and 30 minutes. Thus, the waiting and travel time was similar for both cash and voucher program recipients, and none of the recipients mentioned this as an issue either during the voucher exit fairs, the cash transfer monitoring report, the surveys or the focus group discussions. ${ }^{48}$ Yet a key area where they might differ is the opportunity costs of time: As cash transfer recipients could pick up their cash and shop at any time, they could choose a time when opportunity costs were relatively lower.

A final cost when comparing the cash and voucher program, especially in a highly insecure environment such as eastern DRC, is one of security. ${ }^{49}$ For example, if non-program recipients can easily observe a certain transfer modality, then this could make program recipients easier targets for thieves or

48 In theory, cash transfer recipients were able to obtain their cash from the cooperative during certain days or times, thereby spreading out the number of program recipients on a particular day. While cash recipients could have travelled to the cooperative at different times, voucher recipients had to first wait in line for their vouchers.

49For cash transfer programs, implementing agencies often have one of two choices: 1) distributing the cash transfer themselves, whereby they assume most of the risk; or 2) distributing the cash transfer via the private sector or a quasipublic agency. In the latter context, risk is transferred from the implementing agency to the distribution partner. In both cases, the amount of risk incurred by the program recipients depends upon where and how the cash is distributed, and what happens in the event of theft. 
looters. Or, if a certain transfer modality requires longer travel or wait times to distribute the transfer or requires grouping large number of program recipients, this could put program recipients at greater risk in insecure locations. Overall, the cash transfer program offered greater potential security to program recipients, with lower potential costs in terms of wait. This suggests that the cash transfer program is more effective than the voucher program in this context. ${ }^{50}$

\section{Conclusion}

Redistribution to the poor through welfare transfers plays an important role in the economies of both developed and developing countries, especially those affected by conflict. This paper explores issues surrounding in-kind and cash transfers, using a randomized control trial of cash and vouchers in an internally displaced camp in eastern DRC.

Estimating the relative effects on the transfer on household demand, we find that voucher recipients were more likely to purchase specific items, particularly salt, and in greater quantities. Yet these differential purchases did not translate into differences in consumption or other proxies for well-being.

Some caution is required in terms of interpreting the external validity of these findings. First, while a variety of international organizations use in-kind and voucher transfers, the design and implementation of voucher programs can differ substantially in terms of the values, conditions and eligibility, especially when comparing humanitarian and development voucher programs (Gentilini et al 2014). Second, as we cannot completely address the issue of spillovers, it is possible that the results might differ in contexts where the resale or trade of items purchased with food vouchers is not possible, and in fact, that such spillovers mitigated the distortionary effects of vouchers. And finally, despite the conflict and high transaction costs in eastern DRC, both of which affect the extent of inter-market trade, traders appear to be willing and able to engage in spatial arbitrage, thereby ensuring that supply is available in local markets (UNICEF 2012). This

50Cash program recipients reported that it was easy to conceal the cash while traveling or within the camp. Since voucher recipients had to use their voucher at the voucher fair, and then transport these goods back to the camp, voucher program recipients could have been easier to identify. The only way to reduce the wait time for the voucher program would be to issue vouchers that were redeemable for several days, at pre-arranged vendors, and spread out the registration process over a longer time period. In terms of the location and transport of items purchased with the transfer, in this case, cash recipients were clearly at less risk, as they could choose when, where and how to purchase (and transport) their goods. 
might not be the case in other complex emergencies. Despite these caveats, this research suggests that unconditional cash transfers may be successful in improving households' purchasing power in complex emergencies, while giving households the freedom of choice and at a lower cost. 


\section{References}

Ahmed, A., A. Quisumbing, and J. Hoddinott. 2007. "Relative efficacy of food and cash transfers in improving food security and livelihoods of the ultra-poor in Bangladesh." IFPRI Report submitted to the World Food Programme.

Aker, J. C., R. Boumnijel, A. McClelland and N. Tierney. 2014. "Payment Mechanisms and AntiPoverty Programs: Evidence from a Mobile Money Cash Transfer Experiment in Niger." Unpublished working paper.

Anderson, M. 2008. "Multiple Inference and Gender Differences in the Effects of Early Intervention: A Reevaluation of the Abecedarian, Perry Preschool, and Early Training Projects. " 2008. Journal of the American Statistical Association. 103(484): pp. 1481-1495.

Arimond M, Wiesmann D, Becquey E, Carriquiry A, Daniels MC, Deitchler M, Fanou-Fogny N, Joseph ML, Kennedy G, Martin-Prevel Y, Torheim LE. Simple food group diversity indicators predict micronutrient adequacy of women's diets in 5 diverse, resource-poor settings. Journal of Nutrition 2010;140:2059S-69S .

Arnold, C., T. Conway, and M. Greenslade. 2011. "Cash Transfers: Literature Review.” United Kingdom Department for International Development Policy Division, accessed November 3, 2013, http://r4d.dfid.gov.uk/PDF/Articles/cash-transfers-literature-review.pdf.

Attanasio, O. and A. Mesnard. 2005. "The impact of a conditional cash transfer programme on consumption in Colombia." The Institute for Fiscal Studies, Report Summary Familias 02.

Bailey, S.. "What cash transfers tell us about the international humanitarian community." Humanitarian Exchange Magazine, July 2011.

Baird, S., C. McIntosh and B. Ozler. 2011. "Cash or Condition? Evidence from a Randomized Cash Transfer Program." Quarterly Journal of Economics 126(4): 1709-1753.

Bazzi, S., S. Sumarto and A. Suryahadi. 2013. "It's All in the Timing: Cash Transfers and Consumption Smoothing in a Developing Country." Working Paper.

Benhassine, N., F. Devoto, E. Duflo, P. Dupas, and V. Pouliquen. Forthcoming. "Turning a Shove into a Nudge? A "Labeled Cash Transfer" for Education." American Economic Journal: Policy.

Blattman, C. 2014. "Let Them Eat Cash". The New York Times, June 29. Op-ed available at: http://www.nytimes.com/2014/06/30/opinion/let-them-eat-cash.html?ref=opinion\&_r=3\&referrer=.

Blattman, C. and Niehaus, P. 2014. "Show Them the Money: Why Giving Cash Helps Alleviate Poverty." Foreign Affairs 93(3): 117-126.

Burbidge, John B., Lonnie Magee and A. Leslie Robb. 1988. "Alternative Transformations to Handle Extreme Values of the Dependent Variable" Journal of the American Statistical Association Vol. 83, No. 401, pp. 123-127.

Caldés, N., D. Coady, and J. Maluccio. 2006. "The Cost of Poverty Alleviation Transfer Programs: A Comparative Analysis of Three Programs in Latin America." World Development 34(5): 818-37. 
Coate, S., S. Johnson, and R. Zeckhauser. 1994. "Pecuniary redistribution through in-kind programs." Journal of Public Economics 55(1):19-40.

Cunha, J. 2014. “Testing Paternalism: Cash versus In-Kind Transfers.” American Economic Journal: Applied Economics.

Cunha, J., G.De Giorgi, and S. Jayachandran. 2011. "The Price Effects of Cash versus In-kind Transfers.” National Bureau of Economic Research Working Paper, No. 17456.

Currie, J and F. Gahvari. 2008. "Transfers in Cash and In-Kind: Theory Meets the Data." Journal of Economic Literature 46(2): 333-383.

Daly, G. and F. Giertz. 1972. "Welfare Economics and Welfare Reform." American Economic Review 62(1): 131-38.

De Janvry, A., A. Fargeix, and E. Sadoulet. 1991. "The Political Feasibility of Rural Poverty Reduction." Journal of Development Economics 37(1-2): 351-67.

Deaton, A. S. "Theoretical and Empirical Approaches to Consumer Demand Under Rationing." In Essays in the Theory and Measurement of Consumer Behavior, in honour of Sir Richard Stone, edited by A.S. Deaton, 55-72. Cambridge University Press, 1981.

Del Ninno, Carlo and Paul Dorosh. 2003. "Impacts of in-kind transfers on household food consumption: Evidence from targeted food programmes in Bangladesh." Journal of Development Studies, 40(1): 48-78.

Devereux, Stephan. 2006. "Cash Transfers and Social Protection.” Paper presented at the regional workshop on Cash Transfer Activities in Southern Africa, Johannesburg, South Africa, October 2006.

ECHO. March. 2013. "The Use of Cash and Vouchers in Humanitarian Crises." DG ECHO Funding Guidelines. European Union.

Efron, B., and Tibshirani, R. (1993), An Introduction to the Bootstrap, Boca Raton, FL: CRC Press.

Epple, D. and R. Romano. 1996. "Public Provision of Private Goods." Journal of Political Economy 104(1): 57-84.

Evans, David K. and Anna Popova. 2014. "Cash Transfers and Temptation Goods: A Review of Global Evidence.” World Bank Policy Research Working Paper 6886. Washington, D.C.: The World Bank Group.

Fraker, T., A. Martini, and J. Ohls. 1995. "The Effect of Food Stamp Cashout on Food Expenditures: An Assessment of the Findings from Four Demonstrations." The Journal of Human Resources 30(4): 633-49.

Fisher, Gordon M. 1992. "The Development and History of the Poverty Thresholds" Social Security Bulletin, Vol. 55, No. 4, Winter 1992, pp. 3-14;

Garfinkel, I. 1973. “Is In-Kind Redistribution Efficient?” Quarterly Journal of Economics 87(2): 320-30. 
Garcia, M. and C.M.T. Moore. 2012. The Cash Dividend: The Rise of Cash Transfer Programs in SubSaharan Africa. The World Bank: Washington, D.C.

Gentilini, Ugo. 2014. "Our daily bread : What is the evidence on comparing cash versus food transfers?" Washington, D.C.: The World Bank Group.

Gentilini, Ugo, Maddalena Honorati and Rsulan Yemtsov. 2014. The state of social safety nets 2014. Washington, DC : The World Bank Group.

Glaeser, Edward. "Cash Is Better Than Food Stamps in Helping Poor." Bloomberg News, February 27, 2012, accessed November 3, 2013, http://www.bloomberg.com/news/2012-02-28/cash-better-thanfood-stamps-in-helping-poor-commentary-by-edward-glaeser.html.

Gilligan, D. O, Amy Margolies, Esteban Quinones and Shalini Roy. May 2013. "Impact Evaluation of Cash and Food Transfers at Early Childhood Development Centers in Karamoja, Uganda." IFPRI: Washington, D.C.

Hanrahan, Charles E. 2013. "International Food Aid Programs: Background and Issues," Congressional Research Service, 10.

Hatloy, A., Hallund, J., Diarra, M.M. and Oshaug, A. 2000. "Food variety, socioeconomic status and nutritional status in urban and rural areas in Koutiala (Mali)." Public Health Nutrition, vol 3, pp.57-65.

Hidrobo, M., J. Hoddinott, A. Peterman, A. Margolies and V. Moreira. 2014. "Cash, Food or Vouchers? Evidence from a Randomized Experiment in Northern Ecuador." Journal of Development Economics 107: 144-156.

Hoddindott, J., S. Sandstrom and J. Upton. 2014. "Impact Evaluation of Cash and Food Transfers in Zinder, Niger: Analytical Report.” IFPRI: Washington, D.C.

Hoddinott, J. and Yohannes, Y. 2002. Discussion Paper No. 136: Dietary diversity as a food security indicator. Washington: International Food Policy Research Institute, Food Consumption and Nutrition Division.

Hoynes, H. and D. Schanzenbach. 2009. "Consumption Responses to In-kind Transfers: Evidence from the Introduction of the Food Stamp Program." American Economic Journal: Applied Economics 1(4): 109-39.

Islam, M. and J. Hoddinott. 2009. "Evidence of Intrahousehold Flypaper Effects from a Nutrition Intervention in Rural Guatemala." Economic Development and Cultural Change 57(2): 215-48

Jacoby, H. 2002. "Is There an Intra-household 'Flypaper Effect'? Evidence from a School Feeding Programme." The Economic Journal 112(476): 196-221.

Lacetera N., Macis M., Slonim R. 2012. "Will there be blood? Incentives and displacement effects in prosocial behavior." American Economic Journal: Policy. 4:186-223

Lee, David S. 2009. “Training, Wages, and Sample Selection: Estimating Sharp Bounds on Treatment Effects" The Review of Economic Studies, 6, 1072-1102. 
Maxwell, Daniel and Richard Caldwell. 2008. The Coping Strategies Index: Field Methods Manual.

McKenzie, D. 2012. "Beyond baseline and follow-up: the case for more T in experiments." Journal of Development Economics. 99 (2), 210-221.

MDF Afrique Centrale. September 2009. Concern Worldwide Masisi Programme End Evaluation. Goma, DRC.

Moffitt, R. 1983. "An Economic Model of Welfare Stigma." American Economic Review 73(5): 1023-35.

Moffitt, R. 1989. "Estimating the Value of an In-Kind Transfer: The Case of Food Stamps." Econometrica 57(2): 385-409.

Nichols, A. and R. Zeckhauser. 1982. "Targeting Transfers through Restrictions on Recipients." American Economic Review 72(2):372-377.

Overseas Development Institute (ODI). 2005. Cash and Vouchers in Emergencies. London, UK: Overseas Development Institute.

Overseas Development Institute (ODI). September 2009. An independent evaluation of Concern Worldwide's emergency response in North Kivu, Democratic Republic of Congo: Responding to displacement with vouchers and fairs. London, UK: Overseas Development Institute.

Ozler, Berk. 2013. "Cash Transfers: Sorting Through the Hype". Development Impact, blog post available at: https://blogs.worldbank.org/impactevaluations/cash-transfers-sorting-through-hype.

Rao, S., Yajnik, C.S., Kanade, A., Fall, C.H., Margetts, B.M., Jackson, A.A., Shier, R., Joshi, S., Rege, S., Lubree, H. and Desai, B. 2001. "Intake of micronutrient-rich foods in rural Indian mothers is associated with the size of their babies at birth: Pune Maternal Nutrition Study." Journal of Nutrition, vol 131, pp.1217-1224.

Sadoulet, E., A. de Janvry, and B. Davis. 2001. "Cash Transfer Programs with Income Multipliers: PROCAMPO in Mexico." World Development 29(6): 1043-56.

Sankoh A.J., Huque M.F., Dubey S.D. 1997. "Some comments on frequently used multiple endpoint adjustment methods in clinical trials." Statistics in Medicine. 16:2529-2542.

Save the Children. 2003. Household Economy Analysis of the Rural Population of South-Western Bwito, Rutshuru, North Kivu, Democratic Republic of Congo. Save the Children: DRC.

Sharma, M. 2006. "An Assessment of the Effects of the Cash Transfer Pilot Project on Household Consumption Patterns in Tsunami-Affected Areas of Sri Lanka.” International Food Policy Research Institute, Washington, DC.

Simon, H. A. 1955. “A behavioral model of rational choice.” Quarterly Journal of Economics, 59, 99-118.

Skoufias, E., M. Unar, and T. González-Cossío. 2008. "The Impacts of Cash and In-Kind Transfers on Consumption and Labor Supply." World Bank Policy Research Working Paper No. 4778.

Southworth, H. 1945. "The Economics of Public Measures to Subsidize Food Consumption." Journal of Farm Economics 27(1): 38-66. 
Tabor, S. 2002. "Assisting the Poor with Cash: Design and Implementation of Social Transfer Programs." World Bank Social Protection Discussion Paper No. 0223.

Tobin, J. and H. Houthakker. 1950. "The Effects of Rationing on Demand Elasticities." Review of Economic Studies 18(3):140-153.

UNICEF. 2012. "UNICEF Executive Director visits a 'voucher fair' for vulnerable families in DR Congo." http://www.unicef.org/infobycountry/drcongo_57883.html

Whitmore, D. 2002. "What Are Food Stamps Worth?" Princeton University Industrial Relations Section Working Paper No. 468.

Williams, Christopher. 2013. "Explaining the Great War in Africa: How Conflict in the Congo became a Continental Crisis." Fletcher Forum of World Affairs. 37(2)

Yen, S. T. 2010. "The Effects of SNAP and WIC Programs on Nutrient Intakes of Children." Food Policy 35 (6): 576-583. 
Figure 1. Timeline of Study and Data Collection Activities

\begin{tabular}{|c|c|c|c|c|c|c|c|}
\hline \multicolumn{5}{|c|}{2011} & \multicolumn{3}{|c|}{2012} \\
\hline August & September & October & November & December & January & February & March \\
\hline $\begin{array}{l}\text { Identify } \\
\text { program } \\
\text { participants } \\
\text { (454 } \\
\text { households) }\end{array}$ & 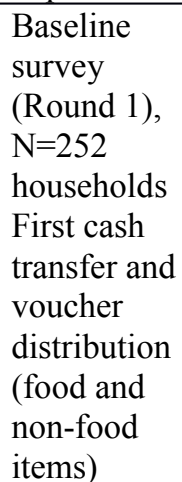 & $\begin{array}{l}\text { Second } \\
\text { cash } \\
\text { transfer } \\
\text { and } \\
\text { voucher } \\
\text { distribution } \\
\text { (food items } \\
\text { only) }\end{array}$ & $\begin{array}{l}\text { Midterm } \\
\text { survey } \\
\text { (Round 2) } \\
\mathbf{N}=138 \\
\text { household } \\
\mathbf{s}\end{array}$ & & Harvest & $\begin{array}{l}\text { Third cash } \\
\text { transfer and } \\
\text { voucher } \\
\text { distribution } \\
\text { (food } \\
\text { items) }\end{array}$ & $\begin{array}{l}\text { Final } \\
\text { evaluation } \\
\text { (Round 3) } \\
\mathbf{N}=\mathbf{1 8 2} \\
\text { households }\end{array}$ \\
\hline
\end{tabular}


Figure 2. Choices Before and After Receiving an Unconditional Cash Transfer or Food Voucher

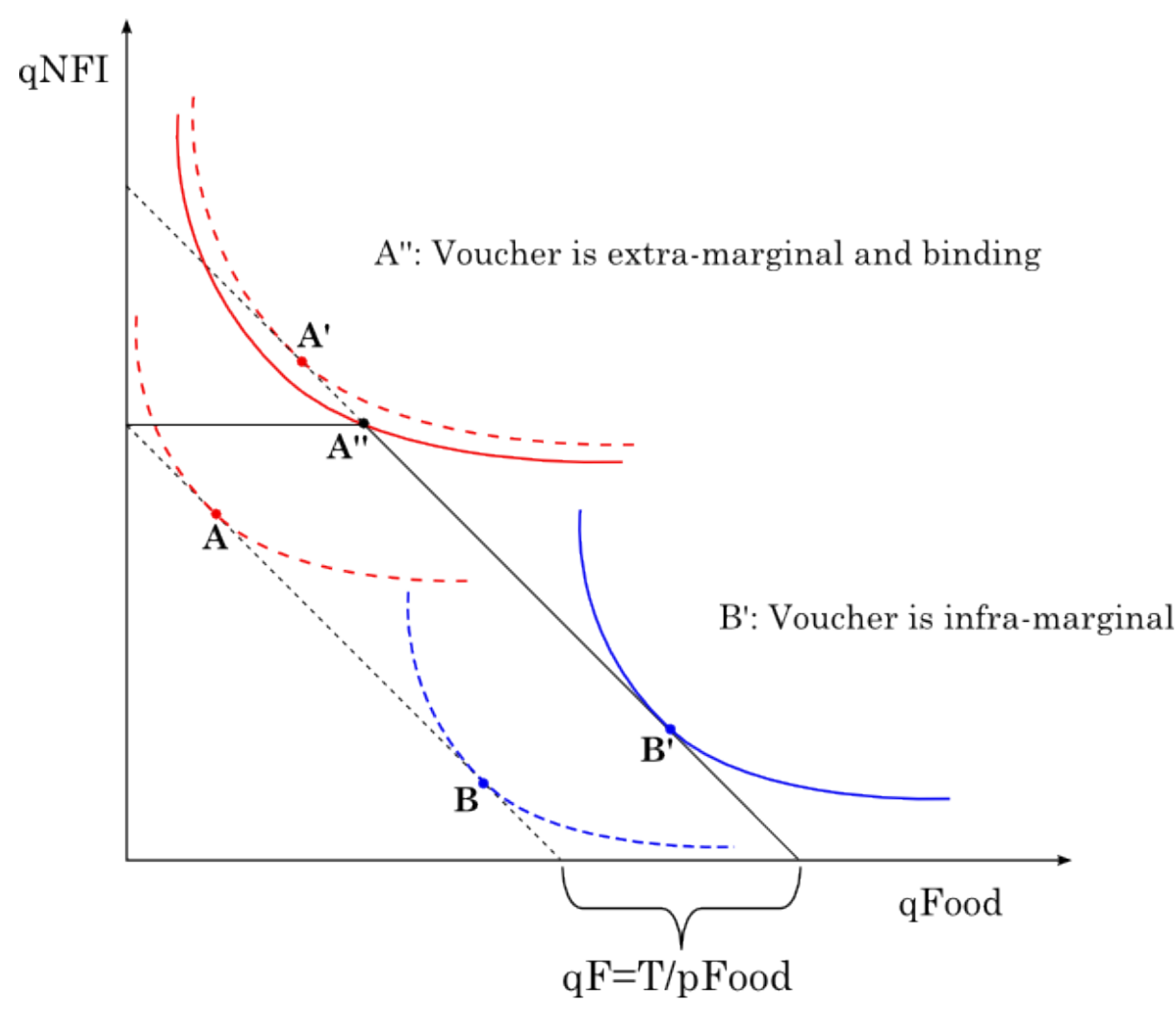

Notes: Adapted from Cunha (2014) and Currie and Gahvari (2008). 
Figure 3. Extra-Marginality of the Voucher

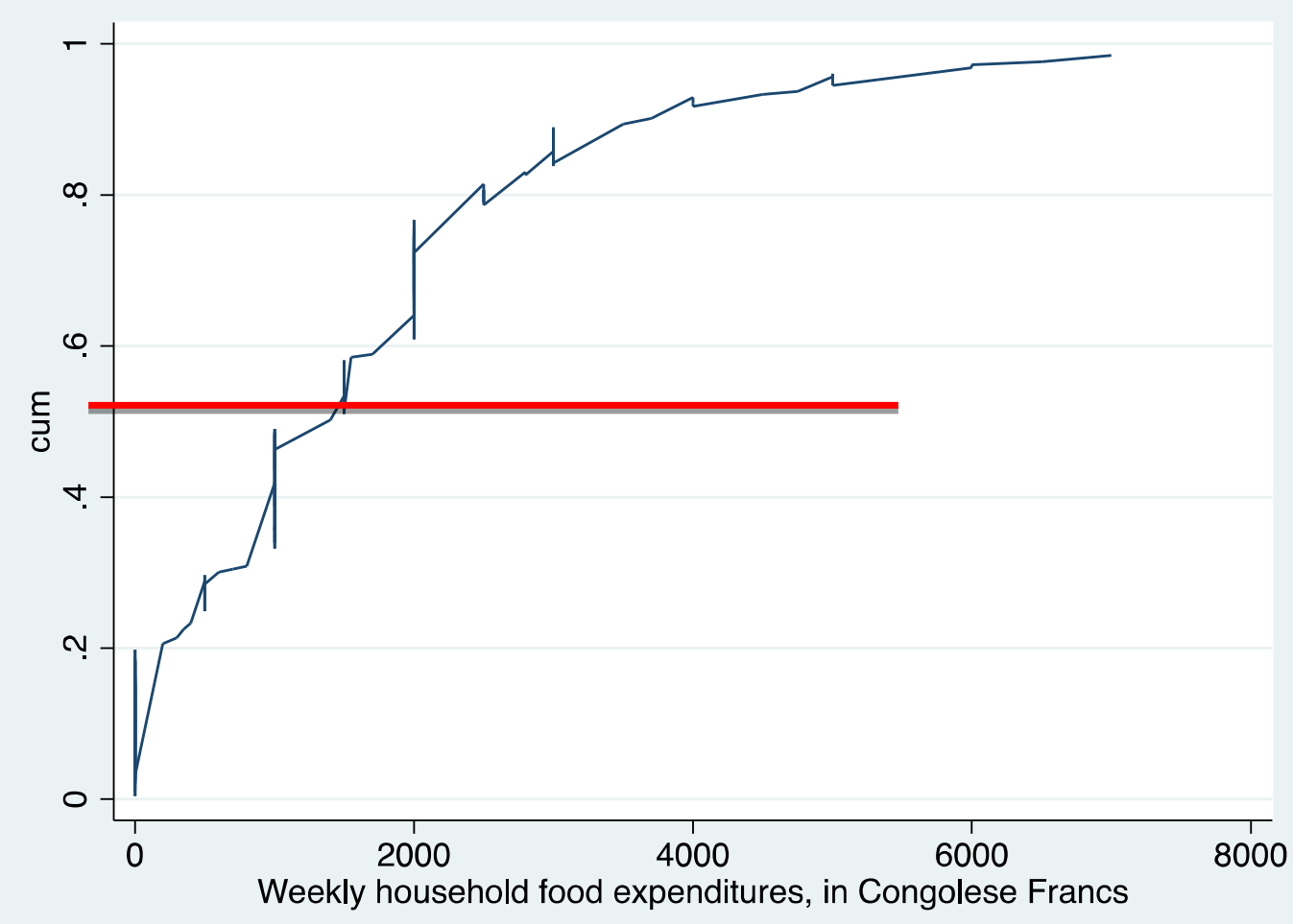

Notes: This figure shows the cumulative density function of weekly household food expenditures (pre-transfer) for the cash transfer group. The red line shows the average value of the transfer for the last two transfers (which could only be spent on food items). 
Figure 4. Costs per Recipient by Transfer Modality (USD)

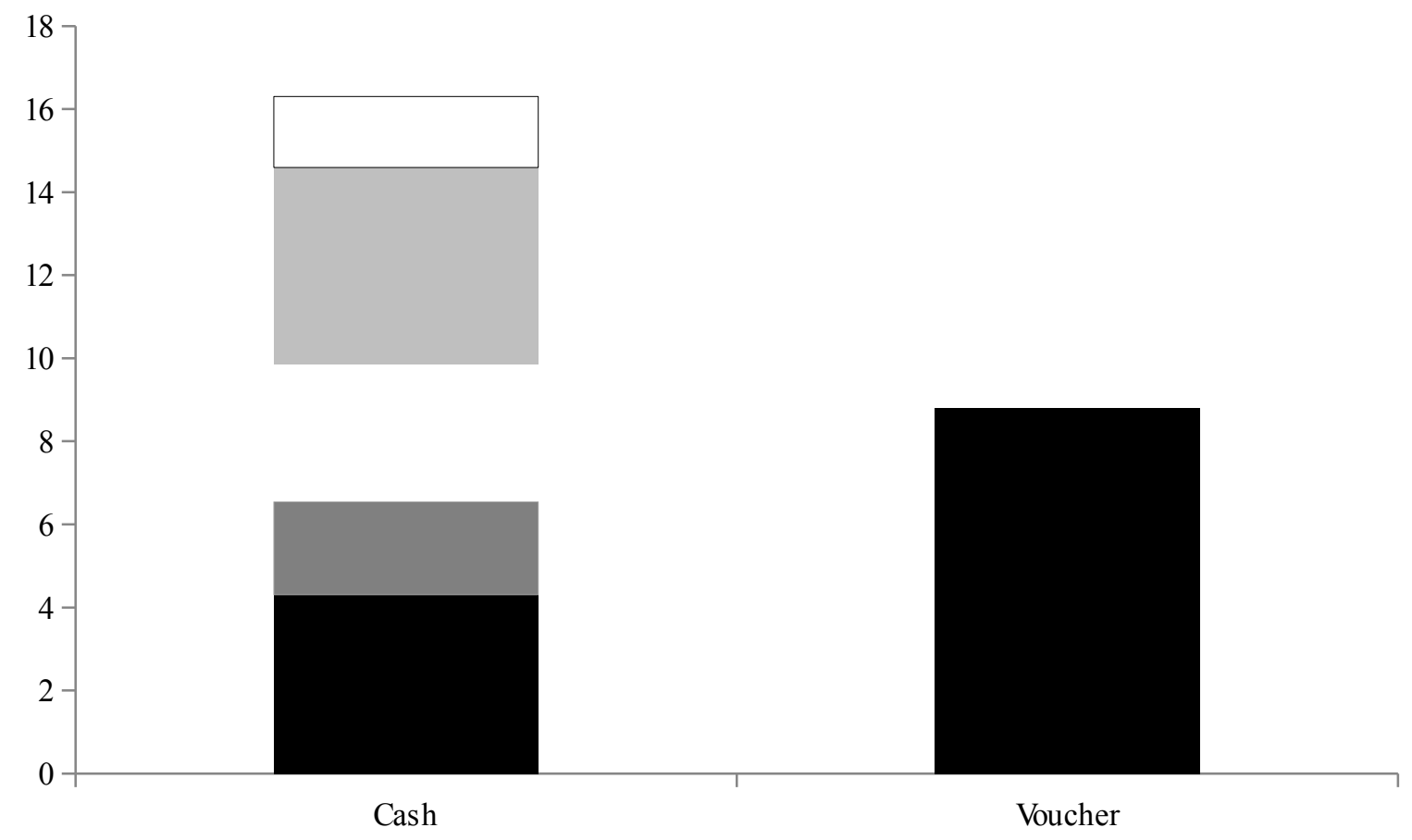

- Transport (fuel, lodging) Materials (plastic sheeting, sticks) Voucher printing Account Opening Costs $\square$ Transfer Fees 


\begin{tabular}{|c|c|c|c|c|c|c|c|c|}
\hline & \multicolumn{4}{|c|}{ Full Sample } & \multicolumn{4}{|c|}{ " Non-Attriters in Third Round } \\
\hline & (1) & (2) & (3) & (4) & $(5)$ & (6) & (7) & $(8)$ \\
\hline Variables & $\begin{array}{c}\text { Voucher } \\
\text { Mean (s.d.) }\end{array}$ & $\begin{array}{c}\text { Cash } \\
\text { Mean (s.d.) }\end{array}$ & $\begin{array}{c}\text { Differenc } \\
\text { e in } \\
\text { Means } \\
\text { p-value }\end{array}$ & $\begin{array}{c}\text { Kolmogorov } \\
\text {-Smirnov } \\
\text { Test } \\
\text { p-value } \\
\end{array}$ & $\begin{array}{l}\text { Voucher } \\
\text { Mean (s.d.) }\end{array}$ & $\begin{array}{c}\text { Cash } \\
\text { Mean (s.d.) }\end{array}$ & $\begin{array}{c}\text { Difference } \\
\text { in Means } \\
\text { p-value } \\
\end{array}$ & $\begin{array}{c}\text { Kolmogorov } \\
\text {-Smirnov } \\
\text { Test } \\
\text { p-value } \\
\end{array}$ \\
\hline \multicolumn{9}{|l|}{ Panel A: Socio-Demographic Characteristics } \\
\hline Household size & $\begin{array}{c}5.40 \\
(2.00)\end{array}$ & $\begin{array}{c}5.55 \\
(1.85)\end{array}$ & 0.314 & 0.933 & $\begin{array}{l}5.67 \\
(2.10)\end{array}$ & $\begin{array}{c}5.66 \\
(1.83)\end{array}$ & 0.657 & 0.981 \\
\hline Number of children (less than 15 years of age) & $\begin{array}{c}4.17 \\
(1.95)\end{array}$ & $\begin{array}{c}4.32 \\
(1.97)\end{array}$ & 0.445 & 0.893 & $\begin{array}{c}4.33 \\
(2.00)\end{array}$ & $\begin{array}{c}4.41 \\
(2.01)\end{array}$ & 0.434 & 1 \\
\hline Program recipient is married & $\begin{array}{c}0.79 \\
(0.41)\end{array}$ & $\begin{array}{c}0.72 \\
(0.45)\end{array}$ & 0.27 & 0.892 & $\begin{array}{c}0.79 \\
(0.41)\end{array}$ & $\begin{array}{c}0.70 \\
(0.46)\end{array}$ & 0.29 & 0.763 \\
\hline Age of program recipient & $\begin{array}{c}34.15 \\
(14.19)\end{array}$ & $\begin{array}{c}34.87 \\
(13.12)\end{array}$ & 0.503 & 0.264 & $\begin{array}{c}34.15 \\
(14.19)\end{array}$ & $\begin{array}{c}34.87 \\
(13.12)\end{array}$ & 0.503 & 0.264 \\
\hline Number of years living in the camp & $\begin{array}{c}1.53 \\
(0.76) \\
\end{array}$ & $\begin{array}{c}1.42 \\
(0.82) \\
\end{array}$ & 0.867 & 0.989 & $\begin{array}{c}1.58 \\
(0.76) \\
\end{array}$ & $\begin{array}{c}1.34 \\
(0.83) \\
\end{array}$ & 0.422 & 0.351 \\
\hline Number of income sources & $\begin{array}{l}1.74 \\
(0.72)\end{array}$ & $\begin{array}{c}1.83 \\
(0.93)\end{array}$ & 0.345 & 0.808 & $\begin{array}{l}1.74 \\
(0.75)\end{array}$ & $\begin{array}{c}1.69 \\
(0.83)\end{array}$ & 0.745 & 0.96 \\
\hline $\begin{array}{l}\text { Total income earned during the past week } \\
\text { (Congolese Franc) }\end{array}$ & $\begin{array}{c}2387 \\
(4610)\end{array}$ & $\begin{array}{c}2491 \\
(4836)\end{array}$ & 0.885 & 0.592 & $\begin{array}{c}2546 \\
(5271)\end{array}$ & $\begin{array}{c}2032 \\
(1870)\end{array}$ & 0.382 & 0.984 \\
\hline $\begin{array}{l}\text { Value of food purchases in the past week } \\
\text { (Congolese Franc) }\end{array}$ & $\begin{array}{c}1883 \\
(4531)\end{array}$ & $\begin{array}{c}1729 \\
(1536)\end{array}$ & 0.678 & 0.175 & $\begin{array}{c}2013 \\
(5092)\end{array}$ & $\begin{array}{c}1672 \\
(1541)\end{array}$ & 0.482 & 0.871 \\
\hline $\begin{array}{l}\text { Per capita value of food purchases in the past } \\
\text { week (Congolese Franc) }\end{array}$ & $\begin{array}{l}371 \\
(879)\end{array}$ & $\begin{array}{l}346 \\
(326)\end{array}$ & 0.633 & 0.587 & $\begin{array}{c}395 \\
(1008)\end{array}$ & $\begin{array}{l}326 \\
(320)\end{array}$ & 0.469 & 0.998 \\
\hline \multicolumn{9}{|l|}{$\begin{array}{l}\text { Panel C: Agricultural Production and } \\
\text { Livestock }\end{array}$} \\
\hline Have access to land & $\begin{array}{c}0.02 \\
(0.15)\end{array}$ & $\begin{array}{c}0.02 \\
(0.13)\end{array}$ & 0.863 & 1.00 & $\begin{array}{c}0.02 \\
(0.15)\end{array}$ & $\begin{array}{c}0.02 \\
(0.13)\end{array}$ & 0.643 & 1.00 \\
\hline Owned poultry & 0.02 & 0.04 & 0.284 & 1.00 & 0.02 & 0.07 & 0.377 & 1.00 \\
\hline
\end{tabular}




\section{$(0.12)$}

$(0.20)$

$(0.14)$

$(0.25)$

\section{Panel D: Asset Ownership}

Total value (USD) of assets

60.60

0.821

0.37

65.72

61.03

0.17

(24.52)

$(25.50)$

Number of durable goods categories owned

0.01

0.01

0.834

(24.64)

(25.69)

(0.09) (0.09)

1.00

0.01

0.01

0.667

$10.87 \quad 11.00$

0.453

0.995

(0.10)

$(0.11)$

$11.17 \quad 10.71$

(3.46)

\section{Panel E: Food Security}

Household diet diversity score (out of 12)

(3.58) (3.55)

(3.48)

0.601

0.54

$2.77 \quad 3.04$

Number of meals in last day (household

1.27

(1.67)

$(0.58)$

1.29

0.204

0.199

2.82

2.81

(1.83)

(1.63)

1.29

1.30

(0.62)

(0.49)

$1.29-1.29$

$0.47)$
1.29

0.908

1.00

1.30

1.29

(0.60)

$(0.50)$

$(0.59) \quad(0.49)$

Months of adequate food provisioning

1.57

$0.49)$
1.86

0.885

1.00

$0.042 * *$

0.418

1.57

1.83

(1.21)

(1.14)

120

253

253

93

89

0.881
0.651
0.875
$0.06^{*}$
182

0.986

1.00

1.00

0.706

182

Notes: Columns 1 and 2 report the unconditional means, with standard deviations in parentheses. Column 3 reports the p-value when testing the hypothesis that the difference between the cash and voucher means is equal to zero. Column 4 reports the p-value from the Kalmogorv-Smirnov test for the equality of distributions. Durable asset categories include a bike, generator and storage facility. Non-durable asset categories include chairs, radios, mattresses and utensils. "Months of adequate food provisioning" are the number of months since the previous harvest that the household felt that it had "enough" food. Household diet diversity is a a list of 12 categories consumed by the household over the past 24 hours. Results are robust to controlling for neighborhood fixed effects, the level of stratification. $* * *$ significant at the 1 percent level, ** significant at the 5 percent level, * significant at the 10 percent level. 


\begin{tabular}{|c|c|c|c|c|}
\hline Panel A: Food Items & $\begin{array}{c}\text { Last Tra } \\
(1) \\
\text { Voucher } \\
\text { Mean (s.d.) }\end{array}$ & $\begin{array}{c}\text { fer Only } \\
(2) \\
\text { Cash } \\
\text { Coeff(s.e.) }\end{array}$ & $\begin{array}{l}\text { Standard p- } \\
\text { value } \\
\text { (3) }\end{array}$ & $\begin{array}{c}\text { Bonferroni } \\
\text { adjusted p-value } \\
\text { (4) }\end{array}$ \\
\hline Number of different purchases made & $\begin{array}{c}3.31 \\
(1.78)\end{array}$ & $\begin{array}{c}3.67 * * * \\
(0.48)\end{array}$ & 0.000 & 0.017 \\
\hline Staple grains (maize, maize flour) & $\begin{array}{c}0.49 \\
(0.50)\end{array}$ & $\begin{array}{c}0.24 * * * \\
(0.07)\end{array}$ & 0.001 & 0.017 \\
\hline Other grains (cassava flour, rice) & $\begin{array}{c}0.61 \\
(0.49)\end{array}$ & $\begin{array}{l}-0.10 \\
(0.08)\end{array}$ & 0.197 & 0.017 \\
\hline Beans & $\begin{array}{c}0.15 \\
(0.36)\end{array}$ & $\begin{array}{c}0.38 * * * \\
(0.07)\end{array}$ & 0.000 & 0.017 \\
\hline Condiments & $\begin{array}{c}0.00 \\
(0.00)\end{array}$ & $\begin{array}{c}0.26 * * * \\
(0.05)\end{array}$ & 0.000 & 0.017 \\
\hline Oil & $\begin{array}{c}0.45 \\
(0.50)\end{array}$ & $\begin{array}{c}0.27 * * * \\
(0.08)\end{array}$ & 0.001 & 0.017 \\
\hline Meat & $\begin{array}{c}0.00 \\
(0.00)\end{array}$ & $\begin{array}{c}0.55^{* * *} \\
(0.06)\end{array}$ & 0.000 & 0.017 \\
\hline Vegetables & $\begin{array}{c}0.04 \\
(0.19)\end{array}$ & $\begin{array}{c}0.35^{* * *} \\
(0.06)\end{array}$ & 0.000 & 0.017 \\
\hline Salt & $\begin{array}{c}0.93 \\
(0.26)\end{array}$ & $\begin{array}{c}-0.13^{* *} \\
(0.05)\end{array}$ & 0.019 & 0.017 \\
\hline Fish & $\begin{array}{c}0.45 \\
(0.50) \\
\end{array}$ & $\begin{array}{l}-0.02 \\
(0.08) \\
\end{array}$ & 0.682 & 0.017 \\
\hline \multicolumn{5}{|l|}{ Panel B: Agricultural Items } \\
\hline Livestock & $\begin{array}{c}0.00 \\
(0.00)\end{array}$ & $\begin{array}{c}0.08 * * \\
(0.03)\end{array}$ & 0.018 & 0.017 \\
\hline Seeds & $\begin{array}{c}0.11 \\
(0.31) \\
\end{array}$ & $\begin{array}{c}0.03 \\
(0.05) \\
\end{array}$ & 0.477 & 0.017 \\
\hline \multicolumn{5}{|l|}{ Panel C: Other Non-Food Items } \\
\hline Clothing & $\begin{array}{c}0.00 \\
(0.00)\end{array}$ & $\begin{array}{c}0.42 * * * \\
(0.06)\end{array}$ & 0.000 & 0.017 \\
\hline Housing Materials & $\begin{array}{c}0.00 \\
(0.00) \\
\end{array}$ & $\begin{array}{c}0.11 * * * \\
(0.03)\end{array}$ & 0.001 & 0.017 \\
\hline \multicolumn{5}{|c|}{ Panel D: Education and Health Expenditures } \\
\hline School fees & $\begin{array}{c}0.01 \\
(0.11)\end{array}$ & $\begin{array}{c}0.65 * * * \\
(0.06)\end{array}$ & 0.000 & 0.017 \\
\hline Medicines & $\begin{array}{c}0.00 \\
(0.00)\end{array}$ & $\begin{array}{l}0.05^{*} \\
(0.03)\end{array}$ & 0.053 & 0.017 \\
\hline Reimburse debts & $\begin{array}{c}0.07 \\
(0.26)\end{array}$ & $\begin{array}{c}0.43^{* * *} \\
(0.06)\end{array}$ & 0.000 & 0.017 \\
\hline Number of observations & & 178 & & \\
\hline
\end{tabular}


Notes: This table presents a simple comparison of means for households in the two treatments. Column 1 shows the mean and s.d. of the basic treatment (voucher) households for the third transfer, whereas Column 2 shows the coefficient and standard error on the cash transfer variable for the third transfer (using the third round of data). Column 4 shows the Bonferroni-adjusted p-value, adjusted for the mean correlation among outcomes. All regressions control for neighborhood fixed effects, the level of stratification prior to randomization. Heteroskedasticity-consistent s.e. are presented in parentheses. $* * *$ significant at the 1 percent level, ** significant at the 5 percent level, * significant at the 10 percent level. 


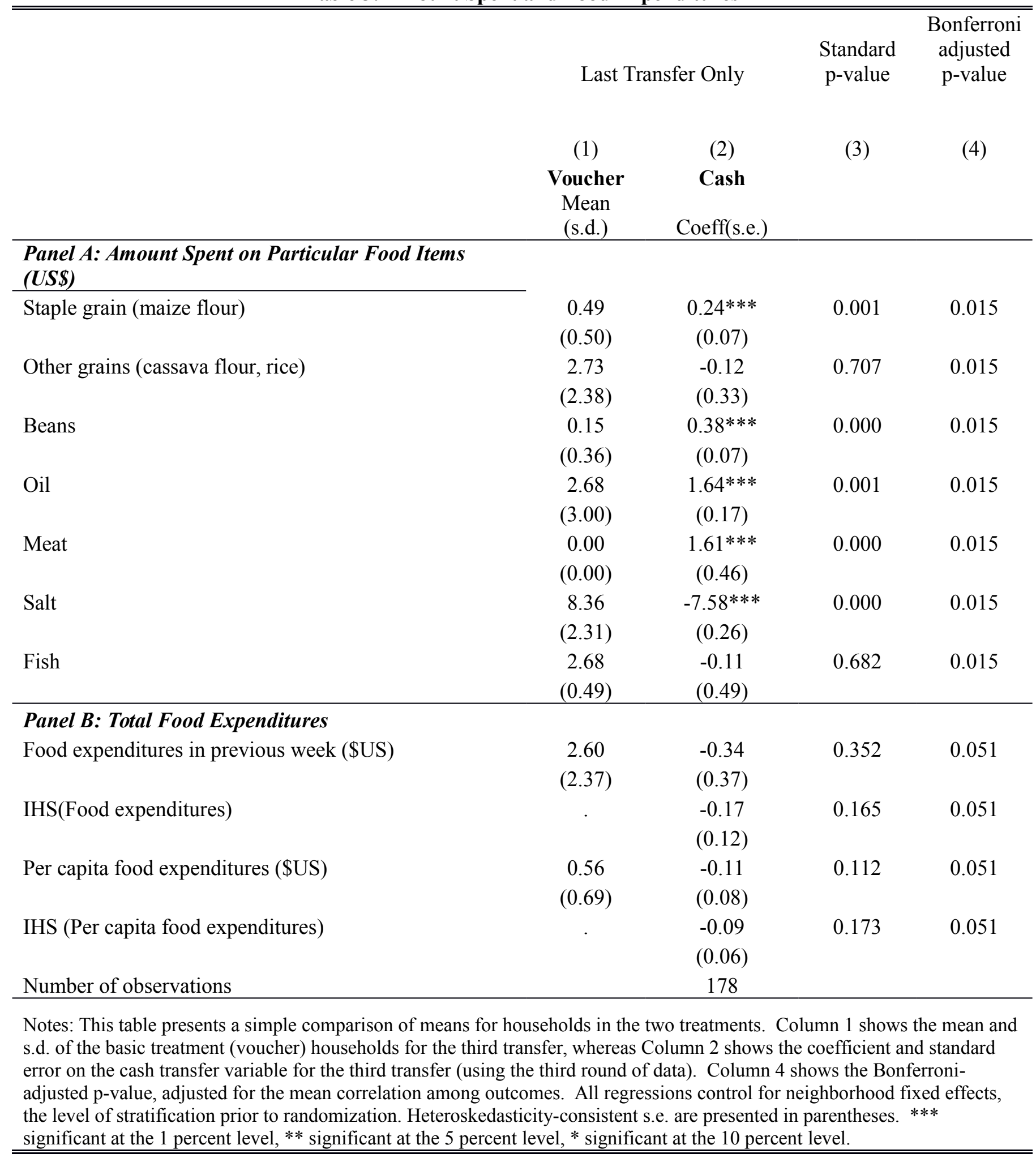




\begin{tabular}{|c|c|c|c|c|}
\hline & \multicolumn{2}{|c|}{ Last Transfer Only } & \multirow{2}{*}{$\begin{array}{l}\text { Standard p- } \\
\text { value } \\
\text { (3) }\end{array}$} & \multirow{2}{*}{$\begin{array}{l}\text { Bonferroni } \\
\text { adjusted p- } \\
\text { value } \\
\text { (4) }\end{array}$} \\
\hline & $\begin{array}{c}(1) \\
\text { Voucher } \\
\text { Mean (s.d.) }\end{array}$ & $\begin{array}{c}(2) \\
\text { Cash } \\
\text { Coeff(s.e.) }\end{array}$ & & \\
\hline \multicolumn{5}{|l|}{ Panel A: Household Diet Diversity } \\
\hline Household diet diversity (out of 12) & $\begin{array}{c}3.09 \\
(1.34)\end{array}$ & $\begin{array}{l}-0.08 \\
(0.22)\end{array}$ & 0.735 & 0.015 \\
\hline Grains & $\begin{array}{c}0.66 \\
(0.47)\end{array}$ & $\begin{array}{c}0.00 \\
(0.08)\end{array}$ & 0.956 & 0.015 \\
\hline Tubers & $\begin{array}{c}0.73 \\
(0.45)\end{array}$ & $\begin{array}{l}-0.01 \\
(0.08)\end{array}$ & 0.935 & 0.015 \\
\hline Beans & $\begin{array}{c}0.19 \\
(0.40)\end{array}$ & $\begin{array}{l}-0.02 \\
(0.07)\end{array}$ & 0.815 & 0.015 \\
\hline Vegetables & $\begin{array}{c}0.65 \\
(0.48)\end{array}$ & $\begin{array}{l}-0.01 \\
(0.08)\end{array}$ & 0.936 & 0.015 \\
\hline Fruits & $\begin{array}{c}0.06 \\
(0.24)\end{array}$ & $\begin{array}{l}-0.03 \\
(0.04)\end{array}$ & 0.448 & 0.015 \\
\hline Fats & $\begin{array}{c}0.37 \\
(0.49)\end{array}$ & $\begin{array}{c}0.02 \\
(0.08)\end{array}$ & 0.71 & 0.015 \\
\hline Eggs & $\begin{array}{c}0 \\
(0.00)\end{array}$ & $\begin{array}{c}0.01 \\
(0.01)\end{array}$ & 0.2 & 0.015 \\
\hline Meat & $\begin{array}{c}0.05 \\
(0.21)\end{array}$ & $\begin{array}{l}-0.03 \\
(0.03)\end{array}$ & 0.4 & 0.015 \\
\hline Fish & $\begin{array}{c}0.12 \\
(0.33)\end{array}$ & $\begin{array}{c}0.04 \\
(0.06)\end{array}$ & 0.51 & 0.015 \\
\hline Condiments & $\begin{array}{c}0.24 \\
(0.15)\end{array}$ & $\begin{array}{c}-0.04 \\
(0.03)\end{array}$ & 0.206 & 0.015 \\
\hline Sugar & $\begin{array}{c}0.24 \\
(0.43) \\
\end{array}$ & $\begin{array}{l}-0.02 \\
(0.07) \\
\end{array}$ & 0.838 & 0.015 \\
\hline \multicolumn{5}{|l|}{ Panel B: Other Food Security Measures } \\
\hline Number of meals per day (household) & $\begin{array}{c}1.37 \\
(0.58)\end{array}$ & $\begin{array}{l}-0.03 \\
(0.10)\end{array}$ & 0.781 & 0.026 \\
\hline Number of meals per day (children) & $\begin{array}{c}2.52 \\
(3.45)\end{array}$ & $\begin{array}{l}-0.51 \\
(0.51)\end{array}$ & 0.274 & 0.026 \\
\hline Months of adequate food provisioning & $\begin{array}{c}1.42 \\
(0.64) \\
\end{array}$ & $\begin{array}{c}0.12 \\
(0.11) \\
\end{array}$ & 0.309 & 0.026 \\
\hline \multicolumn{5}{|c|}{ Panel C: Income, Assets and Coping Strategies } \\
\hline Income in the previous week (US\$) & $\begin{array}{c}3.36 \\
(2.94)\end{array}$ & $\begin{array}{c}0.82 \\
(1.05)\end{array}$ & 0.423 & 0.008 \\
\hline Total value of household assets (US\$) & $\begin{array}{c}89.07 \\
(35.20)\end{array}$ & $\begin{array}{c}0.36 \\
(5.09)\end{array}$ & 0.944 & 0.008 \\
\hline Money left from transfer (US\$) & $\begin{array}{c}0.00 \\
(0.00)\end{array}$ & $\begin{array}{c}0.07 * * \\
(0.03)\end{array}$ & 0.017 & 0.008 \\
\hline
\end{tabular}


Amount of money remaining from the transfer

(US\$)

Poultry ownership

Negative Coping Strategy Index

Number of observations

Notes: This table presents a simple comparison of means for households in the two treatments. Column 1 shows the mean and s.d. of the basic treatment (voucher) households for the third transfer, whereas Column 2 shows the coefficient and standard error on the cash transfer variable for the third transfer (using the third round of data). Column 4 shows the Bonferroni-adjusted p-value, adjusted for the mean correlation among outcomes. All regressions control for neighborhood fixed effects, the level of stratification prior to randomization. Heteroskedasticity-consistent s.e. are presented in parentheses. *** significant at the 1 percent level, ** significant at the 5 percent level, * significant at the 10 percent level. 


\begin{tabular}{|c|c|c|c|c|}
\hline & \multicolumn{2}{|c|}{ Last Transfer Only } & \multirow{2}{*}{$\begin{array}{l}\text { Standard p- } \\
\text { value } \\
\text { (3) }\end{array}$} & \multirow{2}{*}{$\begin{array}{l}\text { Bonferroni } \\
\text { adjusted p- } \\
\text { value } \\
\text { (4) }\end{array}$} \\
\hline & $\begin{array}{c}(1) \\
\text { Voucher } \\
\text { Mean (s.d.) }\end{array}$ & $\begin{array}{c}(2) \\
\text { Cash } \\
\text { Coeff(s.e.) }\end{array}$ & & \\
\hline \multicolumn{5}{|l|}{ Panel A: Location and Timing of Purchases } \\
\hline Market outside camp & $\begin{array}{c}0.00 \\
(0.00)\end{array}$ & $\begin{array}{c}0.98 * * * \\
(0.02)\end{array}$ & 0.000 & 0.01 \\
\hline Spent money in more than one purchase & $\begin{array}{c}0.00 \\
(0.00) \\
\end{array}$ & $\begin{array}{c}0.80 * * * \\
(0.05)\end{array}$ & 0.000 & 0.01 \\
\hline \multicolumn{5}{|l|}{ Panel B: Intra-Household Decision-Making with Respect to Transfers } \\
\hline Program recipient responsible for spending all or part of transfer & $\begin{array}{c}0.95 \\
(0.21)\end{array}$ & $\begin{array}{l}-0.06 \\
(0.04)\end{array}$ & 0.141 & 0.014 \\
\hline Husband responsible for spending part of transfer & $\begin{array}{c}0.43 \\
(0.50)\end{array}$ & $\begin{array}{l}-0.04 \\
(0.08)\end{array}$ & 0.620 & 0.014 \\
\hline Discussed how to use transfer in advance with other family members & $\begin{array}{c}0.80 \\
(0.40) \\
\end{array}$ & $\begin{array}{c}-0.14 * * \\
(0.07)\end{array}$ & 0.048 & 0.014 \\
\hline \multicolumn{5}{|l|}{ Panel C: Sharing of Transfers } \\
\hline Household shared part of money received & $\begin{array}{c}0.18 \\
(0.38)\end{array}$ & $\begin{array}{l}0.13^{*} \\
(0.08)\end{array}$ & 0.100 & 0.046 \\
\hline Household shared part of goods purchased & $\begin{array}{c}0.42 \\
(0.50) \\
\end{array}$ & $\begin{array}{c}-0.18 * * \\
(0.08) \\
\end{array}$ & 0.029 & 0.046 \\
\hline \multicolumn{5}{|l|}{ Panel D: Intra-Household Decision-Making } \\
\hline Husband makes education decisions alone & $\begin{array}{c}0.35 \\
(0.48)\end{array}$ & $\begin{array}{c}0.07 \\
(0.10)\end{array}$ & 0.511 & 0.034 \\
\hline $\begin{array}{l}\text { Husband decides whether to share transfer with other households } \\
\text { alone }\end{array}$ & $\begin{array}{c}0.33 \\
(0.48)\end{array}$ & $\begin{array}{l}-0.06 \\
(0.09)\end{array}$ & 0.553 & 0.034 \\
\hline Husband decides whether/how to save alone & $\begin{array}{c}0.36 \\
(0.48)\end{array}$ & $\begin{array}{l}-0.03 \\
(0.10)\end{array}$ & 0.880 & 0.034 \\
\hline Number of observations & & 178 & & \\
\hline
\end{tabular}

Notes: This table presents a simple comparison of means for households in the two treatments. Column 1 shows the mean and s.d. of the basic treatment (voucher) households for the third transfer, whereas Column 2 shows the coefficient and standard error on the cash transfer variable for the third transfer (using the third round of data). Column 4 shows the Bonferroni-adjusted p-value, adjusted for the mean correlation among outcomes. All regressions control for neighborhood fixed effects, the level of stratification prior to randomization. Heteroskedasticity-consistent s.e. are presented in parentheses. $* * *$ significant at the 1 percent level, $* *$ significant at the 5 percent level, $*$ significant at the 10 percent level. 


\begin{tabular}{|c|c|c|c|c|}
\hline & \multicolumn{2}{|c|}{ Last Transfer Only } & \multirow{2}{*}{$\begin{array}{c}\begin{array}{c}\text { Standard p- } \\
\text { value }\end{array} \\
(3)\end{array}$} & \multirow{2}{*}{$\begin{array}{c}\begin{array}{c}\text { Bonferroni } \\
\text { adjusted p- } \\
\text { value }\end{array} \\
(4)\end{array}$} \\
\hline & $\begin{array}{c}(1) \\
\text { Voucher } \\
\text { Mean (s.d.) }\end{array}$ & $\begin{array}{c}(2) \\
\text { Cash } \\
\text { Coeff(s.e.) }\end{array}$ & & \\
\hline \multicolumn{5}{|l|}{ Panel A: Take Up and Leakage } \\
\hline Received transfer & $\begin{array}{c}1.00 \\
(0.00)\end{array}$ & $\begin{array}{l}-0.01 \\
(0.01)\end{array}$ & 0.354 & 0.015 \\
\hline Number of transfers received & $\begin{array}{c}1.00 \\
(0.00)\end{array}$ & $\begin{array}{l}-0.01 \\
(0.01)\end{array}$ & 0.354 & 0.015 \\
\hline Amount received (Congolese Franc) & $\begin{array}{c}18,329.00 \\
(153.00) \\
\end{array}$ & $\begin{array}{l}36.94 * \\
(19.83) \\
\end{array}$ & 0.064 & 0.015 \\
\hline \multicolumn{5}{|l|}{ Panel B: Illness and Death } \\
\hline Household member affected by illness & $\begin{array}{c}0.80 \\
(0.40)\end{array}$ & $\begin{array}{l}-0.10 \\
(0.08)\end{array}$ & 0.19 & 0.028 \\
\hline Household member died & $\begin{array}{c}0.15 \\
(0.36)\end{array}$ & $\begin{array}{c}0.03 \\
(0.07)\end{array}$ & 0.68 & 0.028 \\
\hline Number of observations & & 178 & & \\
\hline \multicolumn{5}{|c|}{$\begin{array}{l}\text { Notes: This table presents a simple comparison of means for households in the two treatments. Column } 1 \text { shows the } \\
\text { mean and s.d. of the basic treatment (voucher) households for the third transfer, whereas Column } 2 \text { shows the } \\
\text { coefficient and standard error on the cash transfer variable for the third transfer (using the third round of data). } \\
\text { Column } 4 \text { shows the Bonferroni-adjusted p-value, adjusted for the mean correlation among outcomes. All regressions } \\
\text { control for neighborhood fixed effects, the level of stratification prior to randomization. Heteroskedasticity-consistent } \\
\text { s.e. are presented in parentheses. } * * * \text { significant at the } 1 \text { percent level, }{ }^{* *} \text { significant at the } 5 \text { percent level, * } \\
\text { significant at the } 10 \text { percent level. }\end{array}$} \\
\hline
\end{tabular}

